\title{
Turist Rehberlerinin Hizmet Kalitesinin Destinasyon Imajına Etkisi
}

\author{
The Effect of Tourist Guides' Service Quality on Destination Image
}

\author{
Mustafa AKSARAY* \\ Alper ATEŞ**
}

$\ddot{O} Z$

Turist rehberlerinin ve onların hizmet kalitesinin, turistlerin tecrübe yaşadĭ̆ destinasyonda büyük rol oynadı̆̆ açıkça gözlemlenmektedir. Etkileşim içinde bulunduğu turistlerin zihninde kalıcı bir izlenim bırakmaktadırlar. Bu çalışmanın esas amacı, turist rehberlerinin hizmet kalitesinin destinasyon imajina olan etkilerini incelemektir. Ayrica, hizmet kalitesinin destinasyon ile ilişkileri irdelenmiştir. Buna ek olarak, ziyaretçilerin demografik değişkenleri de, araştırmamızın iki temel konusu olan hizmet kalitesi ve destinasyon imajı üzerinde istatistikî olarak nasıl sonuçlar ortaya çıkardĭ̆ araştırılmıştır. Çalışmanın bir diğer amacı da, rehberlerden ne yapması beklendiğini anlamak için farklı görüşleri değerlendirmektir. Çalışmada, tur rehberlerinin ĕgitimi ve karşılaşstı̆̆ zorlukları analiz eden araştırmalara da değinilmiştir. Araştırma kapsamında, Türkiye'nin en çok ziyaret edilen müzelerinden biri olan Mevlana Müzesi'ne ev sahipliği yapması nedeniyle birçok ziyaretçiyi ă̆ırlayan Konya, uygulama alanı olarak seçilmiştir. Örneklemi oluşturan 400 yerli turiste yapılandırılmış veri toplama tekniği olan anketimiz uygulanmıştır. Yapılan analizler sonucunda, turist rehberlerinin hizmet kalitesinin destinasyon imajı üzerinde anlamlı bir etkisi olduğu gözlemlenmiştir.

\section{ANAHTAR KELIMELER}

Turist rehberi, Hizmet Kalitesi, Turist Rehberlerinin Hizmet Kalitesi, Destinasyon, Destinasyon İmaji, Mevlana Müzesi, Konya.

\begin{abstract}
It is clearly observed that tour guides and their service quality played a majör role destination in which tourists had experience. They leave a lasting impression in the minds of tourists who interacted with them. The main purpose of this study is to examine the effects of tourist guides' service quality on the destination image. Besides, the relations between the quality of service and destination have been scrutinized. In addition, it has been researched demographic variables of visitors how statistically results on service quality and destination image, which are two main subject matter of our research, ensued. Another purpose of the work is to evaluate the different views to understand what to expect from the guides. In this work, it has been touched the researches which analyzed the training of tour guiding and the difficulties encountered by tourist guides as well. In the scope of the research, Konya, which welcomes many visitors due to the fact that it hosts the Mevlana Museum is one of the most visited museums in Turkey, has been selected as the application area. Our questionnaire, which is structured data collection technique, has been conducted on 400 domestic tourists representing the sample. As a result of the analyzes made, it has been observed that tourist guides' service quality has a significant effect on destination image.
\end{abstract}

\section{KEYWORDS}

Tourist Guide, Service Quality, Tourist Guides'Service Quality, Destination, Destination Image, Mevlana Museum, Konya.

\begin{tabular}{|c|c|c|}
\hline \multicolumn{2}{|c|}{ Makale Geliş Tarihi / Submission Date } & \multicolumn{1}{c|}{$\begin{array}{c}\text { Makale Kabul Tarihi / Date of Acceptance } \\
\text { O1.02.2019.2019 }\end{array}$} \\
\hline \multirow{3}{*}{ Atıf } & $\begin{array}{l}\text { Aksaray, M., Ateş, A. (2019). Turist Rehberlerinin Hizmet Kalitesinin Destinasyon İmajına Etkisi. Selçuk Üniversitesi } \\
\text { Sosyal Bilimler Meslek Yüksekokulu Dergisi, 22 (1), 112-132. }\end{array}$ \\
\hline
\end{tabular}

\footnotetext{
*Bilim Uzman1, mustafaaksaray@ windowslive.com, ORCID: 0000-0003-1824-7581

*** Dr. Öğr. Üyesi, T.C. Selçuk Üniversitesi Turizm Fakültesi Turizm Rehberliği Bölümü, alpera@ selcuk.edu.tr, ORCID: 0000-0002-4347-7306
} 


\section{GİRIŞ}

Türkiye'de turist rehberliği, yeterlilik alanı oldukça parçalanmış, profesyonel bir meslek dalıdır. Turist rehberleri olarak çalışmak için bireylerin bazı statüleri yerine getirerek kokart almaları gerekmektedir. Ülkemizde şimdilik, ülkesel ve bölgesel olmak üzere iki katmanlı bir tur rehberlik sistemi vardır. Seviye, profesyonel ya da eğitim hiyerarşisi olarak değil; aksine çalışma alanına dayanmaktadır. Eğitim, turist rehberi kokartı almak için bir ön şart olarak gözükse de bu mesleğin icrası için dil yeterliliğine ülkemizde daha çok önem verilmektedir.

Bir tur rehberi bazı noktalarda ülke başkanından daha önemli kişi konumuna gelebilmektedir. Tur esnasında alacağı bilgilerle donanıp giden turistler, o ülkenin imajı hakkındaki düşüncelere doğrudan turist rehberi tarafından sahip olabilirler. Çünkü tura katılan kişiler turist rehberiyle ister istemez yakınlaşmakta, hatta arkadaş olabilmektedir. Turist rehberinin kuracağı yanlış bir cümle ülkemizin imajının olumsuz bir biçimde yansıtılmasını sağlayabilir. Turizmin birden fazla paydaşı ve menfaat sahipleri olması nedeniyle de, tur rehberlerinden farklı beklentiler oluşmaktadır.

Turist rehberinin gerçekleştirdiği performans ve sunduğu hizmetler turistin memnuniyeti ve tekrar ziyaretindeki önemi azımsanamaz. Turizm ve konaklama sektöründeki hizmet kalitesi literatüründe ağıllıklı olarak "odaklanma" müşteri tarafindan algılanan hizmet kalitesinin itici güçleri olmuştur. Yani, hizmet kalitesindeki ön yüz çalışanlarının rolü kabul edilmekle birlikte, az sayıda çalışma, hizmet sağlayıcısına bağlı faktörleri hem sağlayıcı hem de müşteri açısından belirlemiştir. Geleneksel olarak, hizmet kalitesine yönelik araştırma, müşterinin memnuniyetinin, beklenti-algılama teorisi aracılığıyla perspektifinden gerçekleştirilmiştir. Hizmet kalitesi, hizmet seviyesinin müşteri beklentileriyle ne kadar iyi uyum sağladığının bir ölçüsüdür. Turizmin somut olmayan yapısı nedeniyle, bireyler, önceki deneyimlerden veya mevcut bilgilerden yola çıkarak destinasyon imajına dayanan turizm ürünlerini satın almaya başlamışlardır. Ayrıca, evden bir varış noktasına olan hareket turizmin doğasında olan bir olgudur. Bu nedenlerle, destinasyon imajı, turistlerin destinasyon seçimlerini etkileyen önemli faktörler arasındadır. Böylece, destinasyonun nasıl olumlu bir imaj oluşturabileceğini ve potansiyel turistlerin destinasyonlara olan seyahat mesafesi algılarını nasıl etkileyeceğini bilerek anlamak, turizm araştırmacıları için büyük önem taşımaktadır.

\section{TURIST REHBERI}

\subsection{Turist Rehberinin Tanımı}

Günümüzde turizm hem bireysel hem de kitlesel olarak yapılmakta ve özellikle kitlesel gezilerde turist rehberi büyük önem arz etmektedir. Görülen yerlerin hikâyesi ve geçmişi hakkında bilgilenmek turistin ilgisini çekmektedir. Müzelerde ve ören yerlerinde kullanılan elektronik rehber aracılığıyla verilen bilgiler tek düze genel bilgilerle sınırlı kalmaktayken, bir turist rehberi tarafindan anlatılan ilginç bir hikâye o yerin hafizalardan silinmemesine yol açmaktadır. Genel olarak rehberlik "yol göstericilik" kavramını içerir (Ahipaşaoğlu, 2001:42).

Turist rehberinin tanımını yabancı ve yerli kaynaktan göstermek daha aydınlatıcı olacaktır. Turist rehberi Oxford İngilizce sözlüğüne göre, bilhassa yabancı bir ülkede gezen birine öncülük eden veya yol gösteren; özellikle gezgin veya turisti gezdiren ve ona enteresan yerleri göstermek için kiralanan kişi olarak tarif edilmektedir (Çetin ve Kızılırmak, 2012:308). 22 Haziran 2012'de Resmi Gazete'de yayınlanan 6326 sayılı Turist Rehberliği Meslek Kanunu'nun 2. Maddesinin " $h$ " fikrasında turist rehberi "Bu Kanun hükümleri uyarınca mesleğe kabul edilerek turist rehberliği hizmetini sunma hak ve yetkisine sahip olan gerçek kişi" olarak tanımlanmaktadır. Aynı maddenin " 1 " fikrasında ise turist rehberinin sunacağ 1 turist rehberliği hizmet kavramı "Seyahat acentalığı faaliyeti niteliğinde olmamak kaydıyla kişi veya grup hâlindeki yerli veya yabancı turistlerin gezi öncesinde seçmiş oldukları dil kullanılarak ülkenin kültür, turizm, tarih, çevre, doğa, sosyal veya benzeri değerleri ile varlıklarının kültür ve turizm politikaları doğrultusunda tanıtılarak gezdirilmesini veya seyahat acentaları tarafından düzenlenen turların gezi programının seyahat acentasının yazılı belgelerinde tanımladığı ve tüketiciye satıldığı şekilde yürütülüp acenta adına yönetilmesi” şeklinde ifade edilmektedir (6326 Sayılı Turist Rehberliği Meslek Kanunu, 2012).

\subsection{Turist Rehberliğinde Mesleki Gelişim}

Eğitim ve öğretim, rekabet avantajı sağlamanın hedefleri için önemlidir. Pond (1993), rehberlerin eğitilmesi, değerlendirilmesi ve düzenlenmesinin sadece turistler ve rehberler için değil, aynı zamanda bölgeler, şehirler ve tüm toplumlar için de büyük yararlar sağladığına değinmiştir. Eğitim, bir ülkenin ya da bölgenin ihtiyaçlarını karşılamak ve sürdürülebilir kalkınmaya katkıda bulunmak için ivme sağlayıcı bir unsurdur. 
Eğitim ve gelişime rehberlik etmek için farklı yaklaşımlar yapılmıştır. Genel olarak çalışmalar, ikiye bölünmektedir. Birinci yaklaşıma göre Ap ve Wong (2001) ve Zhang ve Chow (2004), lisans eğitiminin resmi eğitim programlarıyla birleştiğinde rehberlik uygulamalarını iyileştirmek için güvenilir yollar üreteceğini savunmuşlardır. Zhang ve Chow (2004) profesyonel ve deneyimli rehberlerin yeni rehberlerin öğretimine dâhil edilmesini tavsiye ederken, Ap ve Wong (2001) şirketlerde yeni rehberlerin çıraklık eğitiminin bir parçası olarak görev almaları gerektiğini bildirmişlerdir.

Tur rehberliği eğitimine ikinci yaklaşım, sosyal ve bilimsel sorgulamaya dayanmaktadır. Bu yaklaşımı savunan araştırmacilar (Holloway, 1981; Cohen, 1985; Cohen vd., 2002), tur rehberlerinin performans1, üstlendiği roller ve rehberli gezinin deneyimi üzerine odaklanmaktadır. Pearce (1984), bir turist rehberi etkileşimini şekillendiren duygusal, bilişsel ve çevresel faktörleri, turist deneyimini ve turun sonrasındaki deneyimi algılamanın önemini vurgulamıştır.

Birçok yazar, tur rehberlerine, seyahat şirketlerinin ve turistlerin mesleki standart ve beklentilerini karşılayabilecek uzmanlık eğitiminin verilmesini bildirmişlerdir. Arreola (1998), tur rehberlerinin grup turunda gerçekleşmesi beklenen rollere ve operatörün beklediği becerilere/bilgiye göre eğitimin önemli olduğunu iddia etmiştir. Cherem (1977), tur rehberlerinin ilk olarak tercümanlık görevini yerine getirmesinin gerekliliğini, ikinci sırada da uzmanlık alanını icra etmesi gerektiğini ifade ederek, gerçek ve doğru bilgiyi teslim etme becerilerinin önemini vurgulamaktadır.

\subsection{Turizm Sektöründe Turist Rehberinin Yeri ve Önemi}

Tarihsel olarak, turist rehberliği en eski insan faaliyetlerinden biridir. Turist rehberliği iki bin beş yüz yıl önce ortaya çıkmış ve o tarihten itibaren modern kitle turizminin başlangıcı ile birlikte endüstrinin önemli bir faktörü haline gelmiştir. Günümüzde, hem tur yöneticileri/ tur liderleri hem de turist rehberleri olmaksızın turizmden bahsetmemiz oldukça zordur (Rabotić, 2010:1).

Dahles (2002), destinasyonun temsil edilmesinde tur rehberlerinin, turist deneyiminin kalitesini, kalış süresini ve yerel bir topluluk için ortaya çıkan ekonomik faydaları etkilemek için stratejik bir faktör oluşturduğunu ileri sürmektedir. Tur rehberleri, destinasyondaki en önemli bileşenlerden biridir. Turistlerin alışmalarını kolaylaştırmakta ve onlara kendileri için bir deneyim yaratmalarında yardımcı olmaktadırlar. Zhang ve Chow (2004)'a göre, turist rehberi, turistler için 'gerçeğin anını' sağlayan ön safta çalışan kişilerdir ve geziyi mükemmelleştirebilmekte veya bozabilmektedir. Turistin tüm destinasyon unsurlarını iyi bir biçimde tecrübe edebilmesi ve destinasyonla olan gerekli bağlantıyı sağlayabilmesi için tur rehberinin arzulanan performansı göstermesi beklenmektedir. Öte yandan destinasyon, üstün bir turizm deneyimi için hazırlanmış olabilir; ancak, profesyonelce çalışmayan bir tur rehberi bu destinasyonun olumlu algılanmasını baltalayabilmektedir. Turistler, destinasyonlarda verilen hizmetlerden ve kendilerinin memnuniyetinden sorumlu olarak tur rehberlerini görmektedirler. Moscardo (1998) 'ya göre rehber, ziyaretçi memnuniyetini artırmakta ve turizm operasyonlarının ticari olarak uygulanabilirliğine katkıda bulunmaktadır. Buna ek olarak, Geva ve Goldman (1991) da, rehberlerin performansını, tekrar satın almayı, ayrıca tur şirketlerinin imajını ve hatta ülkelerini de etkilediğini düşünmektedir. Moscardo (1996) 'ya göre; tur rehberliği, aktif, sorgulayan ve dünyanın bakış açısını yeniden değerlendirme kapasitesine sahip dikkatli ziyaretçiler üretmeye çalışmaktadır.

Rehberler, bir ülkeyi veya bölgeyi ziyaret eden turistlerin memnun ayrilmalarında hayati bir rol oynamaktadır. Ziyaretleri esnasında turistlerle doğrudan etkileşime girme firsatı, ülke/bölgenin imajını doğru yansıtma, destinasyona ilişkin doğru bilgileri verme, turistlerin güvenliğini ve refahını sağlamakla kalmayıp aynı zamanda keyifli ve tatmin edici bir konaklama için onlardan fazlaca sorumlu olmaktadır. Bu nedenle, rehberlerin sahip olması gereken rol ve firsatlar şansa bırakılamaz; destinasyon yöneticileri de dahil olmak üzere paydaşlar tarafından dikkatli bir şekilde takip edilmelidirler.

\subsection{Turist Rehberleri ve Hizmet Kalitesi}

Genel olarak hizmet kuruluşları ve özellikle turizm sektöründe faaliyet gösteren kuruluşlar, hizmet kalitesinin gittikçe artan önemini fark etmeye başlamışlardır. Rekabet gücü ve giderek artan ve farklılaşan taleplerde bulunan müşteriler, durgunluk, küreselleşme baskıları ve rekabet avantajı elde etmek için turizm ve konaklama işletmelerinin hizmet kalitesinin iyileştirilmesine olan ihtiyaçlarını vurgulamaktadırlar. (Boonitt ve Rompho, 2012:53). Turizm temel olarak, bir deneyime karş1 duyulan tepkilere tepki vermek ve bunları geliştirmek için güçlü bir psikolojik yönü içeren hizmet sektörüdür. Bu nedenle, kalite ve verimlilik gibi konuları çevreleyen endişeler gittikçe daha önemli hale gelmektedir (Otto ve Ritchie, 1996:166)

Ev sahibi ülkenin resmi olmayan elçileri olarak tanınan turist rehberleri için temel önkoşullar, dürüstlük, alçak gönüllülük, haysiyet ve güvenilirlik gibi olumlu kişisel, etik ve ahlaki özelliklerdir. Kapsamlı bilgi ve konunun güçlü bir kavranışı, iyi analitik beceriler, tarihi kültürel alanlar için karşılaştırmalı bir bakış açısı, 
sürekli öğrenme ve kişisel zenginleşmeyi taahhüt eden entelektüel nitelikler de aynı derecede önemlidir. Dahası, önemli olan mesleki diğer nitelikler; ziyaretçinin kullandığı dilde gerçekleri anlatma ve sunma yeteneği, gruplara liderlik etme ve düzenleme kapasitesi, duruş, göz teması ve hikâyeleri anlatma becerisidir. Tur rehberleri tarafından sağlanan hizmetlerin kalitesi temel hizmet sunumu, müşteri oryantasyonu, iletişim etkinliği, zamanındalık, problemleri çözebilme, destinasyon bilgisi, dürüstlük ve güvenilirlik, güvenlik düzenlemelerinin bildirimi ve seyahat programında vaat edilen hizmetin sunumu bileşenlerinden meydana gelen genel turist memnuniyeti seviyeleri ile ilişkilidir (Mossberg, 1995; Wang, vd., 2000; Wong, 2001; Heung, 2008; Mak, vd, 2010).

Tur rehberlerinin yerel destinasyonlarda verilen hizmetlerden ve turist memnuniyetinden sorumlu olduğu açıkça görülmektedir. Bunun yanı sıra tur rehberleri, yinelenenin aksine yeni işler türeterek destinasyonların imajını ve hatta turistlerin hizmet kalitesi algısını etkileyebilir. Tur rehberlerinin sadece turistlerin memnuniyetine değil, destinasyona, pazarlamaya ve markaya katkıda bulunduğu kabul edilmektedir (Baum vd., 2007; Mossberg, 1995; Pearce, 1984; Schmidt, 1979; Whipple vd., 1988).

\section{DESTINASYON IMAJI}

\subsection{Destinasyon İmajı Kavramı ve Bileşenleri}

Hunt (1971), destinasyon imajı üzerine çalışmalar başlatan ilk araştırmacılardan biridir. Destinasyon imajını, bir kişi ya da normal yerleşim yerlerinden başka bir yere hareket eden bir grup insan tarafindan düzenlenen izlenim olarak tanımlamıştır. Crompton (1979), destinasyon imajının belirli bir yerin inançlarını, fikirlerini ve izlenimlerini bir araya getirdiğine işaret etmektedir. Lawson ve Baud-Bovy (1977), destinasyon imajın1, bir birey veya bir grup insan tarafindan tutulan belirli bir yerin bilgisinin, izlenimlerinin, önyargılarının, hayallerinin ve duygularının genel bir ifadesi olarak tanımlamaktadır. Markin (1974) destinasyon imajını, bir bireyin mekânı hakkında bilinen her şeyin kişiselleştirilmesi, içselleştirilmesi ve kavramsallaştırılması olarak belirtmiş̧ir. Reynolds (1985) ise, tüketiciler tarafından algılanan sonsuz izlenimler arasından seçilen birkaç izlenimden geliştirilen psikolojik bir kavram olarak tanımlamıştır. Ayrıca, seçilen imajlar genellikle karmaşık güzelleştirme ve yeniden örgütlenme sürecinden geçmektedir. İmajlar daha sonra bir destinasyon imajına dönüştürülür. Milman ve Pizam (1995) destinasyon imajını bir mekânın görselleştirilmesi ya da psikolojik izlenim olarak bir ürün ya da genel kamusal imajın deneyimi olarak tanımlamışlardır.

Önceki çalışmalar, destinasyon imajının etrafinda kavramsal çerçevenin eksikliğini kabul etmiştir. Süreçte ve destinasyon imaj1 oluşumunun doğasında hâlâ bir fikir birliği yoktur. Fakeye ve Crompton (1991) "bu tür araştırmalar turizm gündeminin bir parçası haline gelmiş olsa da, her zaman kavramsal bir çerçevede eksiktir" görüşünü savunmaktadır. Echtner ve Ritchie ise (1991) "araştırmacılar destinasyon imajını tamamen kavramsallaştırmak ve işlemek için başarılı olamamıştır" ifadesini kullanmıştır. Sonuç olarak, bu konu otuz yılı aşkın bir süredir geniş bir şekilde tartışılsa da, destinasyon imajı kavramını ve boyutlarını daha iyi anlamaya ihtiyaç vardır.

Echtner ve Ritchie (1991) tarafindan geliştirilen destinasyon imajının kavramsal çerçevesi, Şekil 1'de gösterilmiştir. Çerçeve, üç devamlılıktan oluşmaktadır. Destinasyon imajı, mekânın daha bütünsel imajları (zihinsel imajlar) kadar bireysel özniteliklerin algılarından da (iklim, konaklama tesisleri, insanların dostluğu gibi) oluşması gerektiğini öne sürmüştür. İşlevsel imajlar, doğrudan gözlemlenebilir veya ölçülebilir olmasının yanı sıra psikolojik imajlar, daha az somut, gözlemlenmesi veya ölçülmesi daha zordur. Ortak-benzersiz hakkında Echtner ve Ritchie (1993) süreklilik açısından şöyle demiştir: “.. destinasyon imajı 'ortak' özelliklerine dayanan bu algılardan ‘özgün' özellik ya da auralara dayanan algılar farklılıklar içerebilir”. 


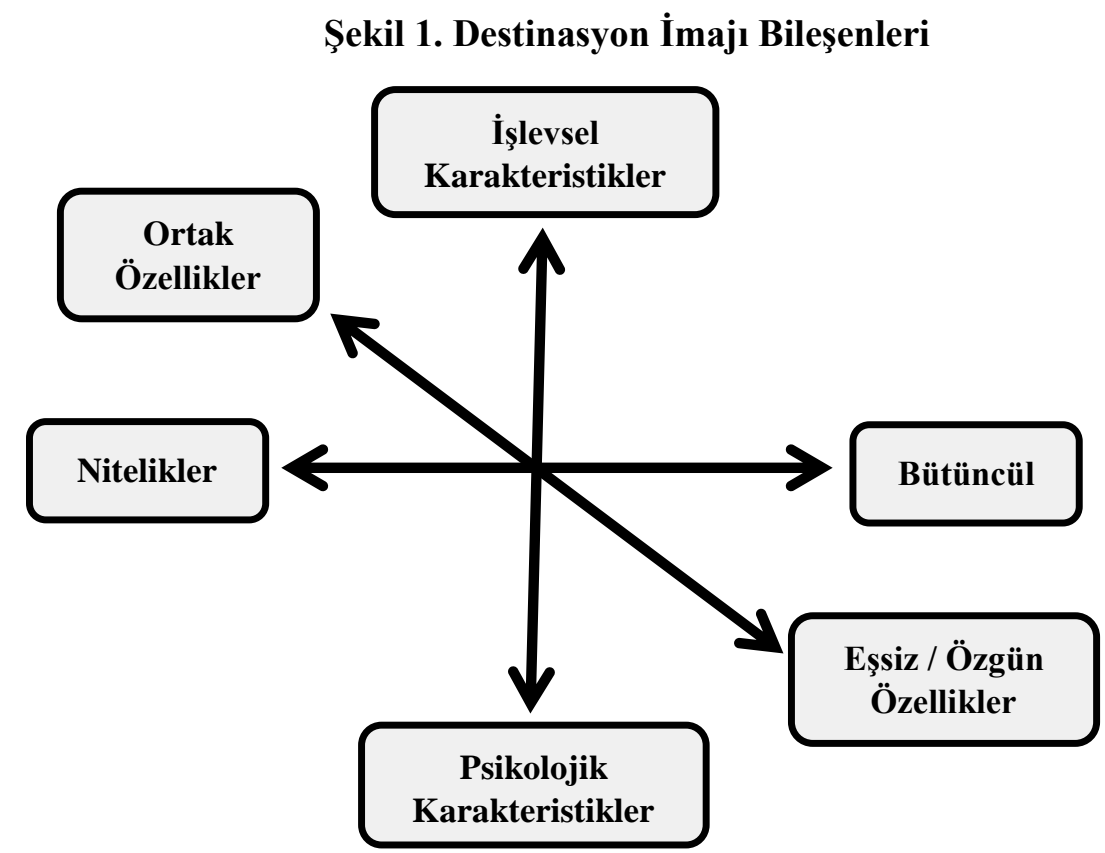

Kaynak: Echtner, C. M. and J. R. B. Ritchie (1991), The Meaning and Measurement of Destination Image, The Journal of Tourism Studies, Vol. 2, No.2, (December), p. 8.

\section{TURIST REHBERLERININ HIZMET KALITESININ DESTINASYON IMMAJINA ETKISİ}

\subsection{Araştırmanın Amacı ve Önemi}

$\mathrm{Bu}$ araştırmanın temel amacı turist rehberlerinin turistler tarafından algılanan hizmet kalitelerinin, destinasyon imajına etkisinin olup olmadığının değerlendirilmesidir. Ayrıca turist rehberlerinin yukarıda belirtilen özellikleri ile yerli turistlerin sahip oldukları demografik özellikler arasında istatiksel olarak bir farklılık olup olmadığı ise diğer bir amaç olarak değerlendirilecektir. Bu araştırma çalışmasının turizm rehberliği alanına literatür derlemesiyle katkı sağlanacağı gibi yapılan araştırma ile yerli turistler açısından bu nitelik ve yeterlilikler değerlendirilmiştir. Ayrıca ilgili literatürde büyük oranda yabancı turistlere hizmet veren rehberlere yer verilerek araştırma alanı yabancılarla sınırlı tutulmuştur. Bu çalışma ile yerli turistlerden elde edilen veriler ortaya konularak bu alandaki veri eksikliğinin giderilmesine yardımcı olunacaktır.

\subsection{Araştırmanın Kapsamı ve Kısıtlılıkları}

Ülkemizdeki her turist rehberi ve turiste ulaşmanın güç olması ve çalışmanın maliyeti nedeniyle araştırmanın Konya ili kapsamında yapılacak olması bir sınırlılık oluşturmaktadır. Araştırma verilerinin toplandığı aylar başı ıaşına bir sınırlılık oluşturmasının yanı sıra, bu aylarda anketin uygulanacağı bölgeye gelen turistlerle yapılacak olması da bir sınırlılık oluşturacaktır. Anket katılımcılarından kolayda örnekleme yöntemi ile veri toplanması sonuçların genellemesi açısından bir kısıtlılık yaratabilir. Veri toplama süresinin turizmin ve turistin yoğun olduğu aylarda olup olmaması da bir sınırlılık olarak değerlendirilebilir. Diğer bir kısıt ise, anketlerin sadece rehber eşliğinde tura çıkan turistlere tur esnasında yapılmasıdır.

\subsection{Veri Toplama Aracı}

Araştırmada kullanılan anket formu üç bölümden oluşmaktadır. İlk bölümde hizmet kalitesi algısını ölçmek amacıyla, termal turizme katılan turistlerin hizmet kalitesi ve destinasyon imaji algılarının tekrar ziyaret niyetleri üzerindeki etkilerini araştırdığı çalışmasında Timur (2015)'un kullandığı ölçekten; Keskin (2013)'in kullandığı ölçekten; ve son olarak Değirmencioğlu (2001)'nun doktora tezinde 2000 yılında Türkiye'yi ziyaret etmeyi hedefleyen Fransız turistlere uyguladığı ve onların rehberlik hizmetinden duyduğu beklenti ve algılarını ölçmek için kullandığı ölçekten faydalanılarak Parasuraman vd. (1988) tarafından geliştirilen 22 maddelik SERVQUAL ölçeği kullanılmıştır. Araştırmada kullanılan yeni ölçeğin testi yapıldığında güvenilirlik yeterli bulunmuştur (Tablo 1). İkinci bölümde ise destinasyon imajının boyutlarından olan duygusal imaj algılarını ölçmek için 4 madde, bilişsel imaj algılarını ölçmek için 13 madde ve genel imaj algılarını ölçmek için 1 maddeden oluşan ölçek kullanılmıştır. Bu ifadelerin tamamı Baloğlu ve McCleary (1999)'nin çalışmasında kullandığı destinasyon imajı ölçeğinden uyarlanmıştır. Yaraşlı (2007)'nın çalışmasında Trabzon'un destinasyon imajının destinasyon seçimindeki önemini ölçmek için kullandığı ölçekten faydalanılmıştır. Bu 
bölümlerde beş aralıklı likert tipi metrik ifadelerden (1-Kesinlikle Katılmıyorum, 2- Katılmıyorum, 3Kararsızım, 4- Katılıyorum, 5- Kesinlikle Katılmıyorum) yararlanılmıştır. Anketin üçüncü bölümünde ise demografik (cinsiyet, yaş, medeni durum, eğitim, meslek ve gelir düzeyi) ifadeler bulunmaktadır.

\section{Tablo 1: Anket Güvenilirlik Analizi}

\begin{tabular}{|c|c|}
\hline Cronbach Alfa Katsayısı & İfade Sayısı \\
\hline, 879 & 40 \\
\hline
\end{tabular}

Tablo 1 Cronbach Alfa Katsayısı yönteminde katsayının, 0 ile 1 arasındaki değişimini göstermektedir. Cronbach's Alfa Katsayısı 0.80-1.00 aralığında olduğundan $(\alpha=0,879)$, anketin genel güvenilirliğinin yüksek derecede olduğu gözlemlenmiştir.

Tablo 2: Araştırmada Kullanılan Ölçeklerin Güvenilirlik Analizi

\begin{tabular}{|c|c|c|c|}
\hline \multicolumn{2}{|r|}{ Ölçekler } & İfade Sayısı & Cronbach Alfa Katsayısı \\
\hline \multirow{5}{*}{ Hizmet Kalitesi } & Somut Ögeler & 5 & ,766 \\
\hline & Güvenilirlik & 4 & ,716 \\
\hline & Empati & 4 & 726 \\
\hline & İsteklilik & 5 & ,741 \\
\hline & Güvence & 4 & 740 \\
\hline \multirow{3}{*}{$\begin{array}{l}\text { Destinasyon } \\
\text { İmajı }\end{array}$} & Duygusal İmaj & 4 & 823 \\
\hline & Bilişsel İmaj & 13 & 839 \\
\hline & Genel İmaj & 1 & ,709 \\
\hline
\end{tabular}

Tablo 2'deki sonuçlarda ölçeklerin alfa katsayı değerlerinin 0,70 ile 1 arasında olması neticesinde yüksek oranda güvenirliliğe sahip olduğu gözlemlenmektedir.

\subsection{Araştırmanın Evren ve Örneklemi}

Konya'yı ziyaret eden yerli turistler araştırmanın evrenini oluşturmaktadır. Resmi verilere göre, 2017 yılında Konya'yı ziyaret eden kişi sayısı 2.614.634'tür. Araştırmanın yapıldığı Şubat ve Mart ayı (2018) içerisinde ise Konya'yı ziyaret eden turist sayısının 341.522 olduğu belirtilmiştir. Müzekart uygulamasına

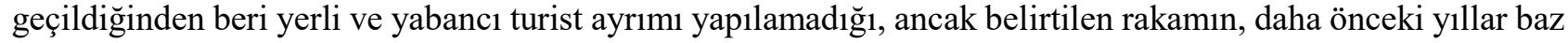
alınarak yaklaşık olarak 1/3'ünün yabancı olduğu bilgisi verilmiştir. 2018 yılı için Şubat ve Mart aylarında 227.600 kişiden fazla yerli ziyaretçinin Konya'yı ziyaret ettiği bilgisi tarafımıza ulaşmıştır (Konya İl Kültür ve Turizm Müdürlüğü, 2018).

Belirtilen değerlerin de 10.000 'in üzerinde olması sebebiyle, örneklem büyüklüğunnün belirlenmesinde, sınırsız evren örneklem formülünden ( $n=$ p.q.z2 $\alpha / \mathrm{e} 2)$ yararlanılmıştır. Örneklem büyüklüğü, varyans1 maksimum kılan oran (p: 0,50) dikkate alınarak $\% 5$ anlam düzeyinde ve $\% 5$ örneklem hatası ile 384 kişi olarak ( $\mathrm{n}=$ p.q.z2 $\alpha / \mathrm{e} 2=1,962 \times 0,5 \times 0,5 / 0,052=3,8416 \times 0,25 / 0,0025=384)$ tespit edilmiştir (Ural \& K1lıç, 2006:47). Belirlenen 384 kişilik örneklem büyüklüğü yaşanılacak herhangi bir problem göz önüne alınarak 400 seviyesine yükseltilmiştir. Örneklem olarak, olasılığa dayalı olmayan örneklem çeşidi olan kolayda örnekleme yöntemi kullanılmıştır. Bu yöntem, ankete katılan herkesin örnekleme dahil edilebilmesi esasına dayanır (Altunışık, vd., 2010:139-140). Zaman tasarrufunu sağlaması ve ekonomik bir şekilde veri elde edilmesi bakımından bu teknik tercih edilmiştir (Nakip, 2006:204). Böylece, 1 Şubat - 31 Mart 2018 tarihleri arasında bir tur kapsamında Konya'yı ziyaret eden yerli turistler arasından anketi cevaplamaya gönüllü olanlar, kolayda örnekleme yöntemiyle ele alınmıştır.

\subsection{Uygulanan İstatistiksel Yöntemler}

Araştırmamızda elde edilen verilerin analizi için "SPSS 16.0 for Windows" paket programı kullanılmıştır. Öncelikle, anketin ve ankette bulunan hizmet kalitesi ve destinasyon imajı alt boyutlarının güvenilirlik analizi Cronbach Alfa katsayısı uygulanmıştır. Demografi ile alakalı çoklu bağımsız değişkenlerin analizi için Kruskal Wallis H-Testi uygulanırken, ikili bağımsız değişkenlerin analizi için de Mann Whitney-U Testi uygulanmıştır. Çalışmamızın ölçeklerinde yer alan bağımlı değişkenin bağımsız değişken(ler) tarafından nasıl açıklandığını belirlemek amacıyla da çoklu regresyon analizi yapılmıştır.

\subsection{Araştırmanın Modeli ve Hipotezleri}

Turist rehberi, hizmet kalitesi ve destinasyon imajı konularıyla alakalı daha önce yapılmış araştırmalar ve teorik yaklaşımlar (Mossberg, 1995; Wang vd., 2000; Wong, 2001; Heung, 2008; Mak vd., 2010; Baum vd., 2007; Mossberg, 1995; Pearce, 1984; Schmidt, 1979; Whipple vd., 1988) sonucunda, çalışmanın kavramsal 
çerçeve bölümünde hipotezlerinin kaynak olarak alındığı bilgiler sunulmuştur. Bu araştırmanın hipotezlerinin daha açık anlaşılması, amacına uyması, verilerin toplanması ve çözümlenebilmesi amacıyla (Karasar, 2012: 76) hipotezlerin bir model içerisinde şekilsel olarak verilmesi düşünülmüştür.

H1: Turist rehberlerinin hizmet kalitesinin destinasyon imajına etkisi vardır.

H1.1: Turist rehberlerinin algılanan hizmet kalitesinin somut öğeleri boyutu, duygusal destinasyon imaj1 algisında pozitif ve anlamlı düzeyde etkilidir.

H1 .2: Turist rehberlerinin algılanan hizmet kalitesinin somut öğeleri boyutu, bilişsel destinasyon imaj1 algisında pozitif ve anlamlı düzeyde etkilidir.

H1.3: Turist rehberlerinin algılanan hizmet kalitesinin somut öğeler boyutu, genel destinasyon imaj1 algisında pozitif ve anlamlı düzeyde etkilidir.

H1.4: Turist rehberlerinin algılanan hizmet kalitesinin güvenilirlik boyutu, duygusal destinasyon imaj1 algisında pozitif ve anlamlı düzeyde etkilidir.

H1.5: Turist rehberlerinin algılanan hizmet kalitesinin güvenilirlik boyutu, bilişsel destinasyon imaj1 algisında pozitif ve anlamlı düzeyde etkilidir.

H1.6: Turist rehberlerinin algılanan hizmet kalitesinin güvenilirlik boyutu, genel destinasyon imaj1 algisında pozitif ve anlamlı düzeyde etkilidir.

H1.7: Turist rehberlerinin algilanan hizmet kalitesinin empati boyutu, duygusal destinasyon imaj1 algisinda pozitif ve anlamlı düzeyde etkilidir.

H1.8: Turist rehberlerinin algılanan hizmet kalitesinin empati boyutu, bilişsel destinasyon imajı algısında pozitif ve anlamlı düzeyde etkilidir.

H1.9: Turist rehberlerinin algilanan hizmet kalitesinin empati boyutu, genel destinasyon imaji algisında pozitif ve anlamlı düzeyde etkilidir.

H1.10: Turist rehberlerinin algilanan hizmet kalitesinin isteklilik boyutu, duygusal destinasyon imaj1 algisında pozitif ve anlamlı düzeyde etkilidir.

H1.11: Turist rehberlerinin algılanan hizmet kalitesinin isteklilik boyutu, bilişsel destinasyon imaj1 algisında pozitif ve anlamlı düzeyde etkilidir.

H1.12: Turist rehberlerinin algılanan hizmet kalitesinin isteklilik boyutu, genel destinasyon imajı algısında pozitif ve anlamlı düzeyde etkilidir.

H1.13: Turist rehberlerinin algilanan hizmet kalitesinin güvence boyutu, duygusal destinasyon imaj1 algisında pozitif ve anlamlı düzeyde etkilidir.

H1.14: Turist rehberlerinin algılanan hizmet kalitesinin güvence boyutu, bilişsel destinasyon imajı algisında pozitif ve anlamlı düzeyde etkilidir.

H1.15: Turist rehberlerinin algılanan hizmet kalitesinin güvence boyutu, genel destinasyon imajı algisında pozitif ve anlamlı düzeyde etkilidir.

H.1.16: Cinsiyet, turist rehberlerinin hizmet kalitesi algısında istatistikî olarak anlamlı farklar ortaya koymaktadır.

H1.17: Cinsiyet, destinasyon imajı algisında anlamlı farklar ortaya koymaktadır.

H1.18: Yaş, turist rehberlerinin hizmet kalitesi algısında istatistikî olarak anlamlı farklar ortaya koymaktadir.

H1.19: Yaş, destinasyon imajı algısında istatistikî olarak anlamlı farklar ortaya koymaktadır.

H1.20: Medeni durum, turist rehberlerinin hizmet kalitesi algısında istatistikî olarak anlamlı farklar ortaya koymaktadir.

H1.21: Medeni durum, destinasyon imajı algısında istatistikî olarak anlamlı farklar ortaya koymaktadır.

H1.22: Eğitim durumu, turist rehberlerinin hizmet kalitesi algısında istatistikî olarak anlamlı farklar ortaya koymaktadır.

H1.23: Eğitim durumu, destinasyon imajı algısında istatistikî olarak anlamlı farklar ortaya koymaktadır.

H1.24: Meslek, turist rehberlerinin hizmet kalitesi algısında istatistikî olarak anlamlı farklar ortaya koymaktadir.

H1.25: Meslek, destinasyon imajı algısında istatistikî olarak anlamlı farklar ortaya koymaktadır.

H1 26: Aylık ortalama gelir düzeyi, turist rehberlerinin hizmet kalitesi algısında istatistikî olarak anlamlı farklar ortaya koymaktadir.

H1.27: Aylık ortalama gelir düzeyi, destinasyon imajı algısında istatistikî olarak anlamlı farklar ortaya koymaktadır. 
Şekil 2: Araştırma Modeli

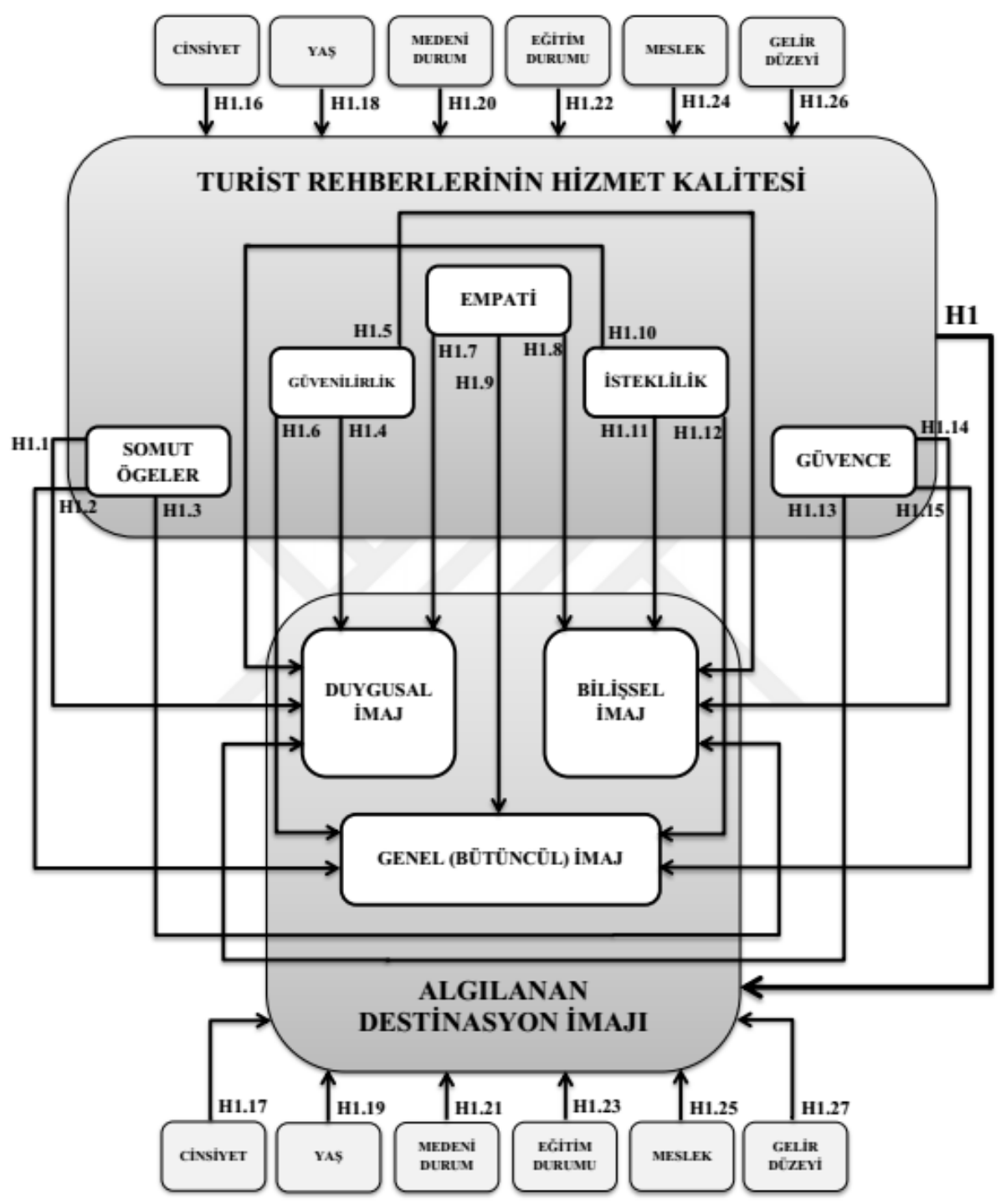

\section{ARAŞTIRMA BULGULARI}

\subsection{Katılımcıların Demografik Özellikleri}

Katılımcıların \%59,25'i (237) erkeklerden, \%40,75'i (163) ise kadınlardan oluşmaktadır. Ziyaretçilerin yaş ortalamasına bakıldığında $\% 35,75^{\prime}$ lik bir oranla $18-25$ yaş arasındaki gençlerden oluşmaktadır. Anket yapılan kişilerin medeni halleri (Bekâr-Evli) ise \%52 ve \%48 gibi oranlarla neredeyse eşitlik göstermektedir. Katılımcıların \%58,50'si lisans mezunudur. Cevaplayıcıların eğitim durumunu gösteren geriye kalan \%41,50'lik oran ise sırasıyla lise ve dengi, yüksek lisans, ilköğretim ve doktora mezunlarından oluşmaktadır. Ankete katılanların büyük bir çoğunluğunu $(\% 47,75)$ öğrenci ve özel sektör çalışanı ziyaretçiler oluşturmaktadır. Diğer katılımcıların meslek grupları ise sırasıyla Kamu Çalışanı (\%9,25), Emekli (\%9), Kamu Yöneticisi (\%6) ve Özel Sektör Yönetici (\%6), Avukat (\%5,50), Serbest Meslek (\%5), Özel Sektör İşveren $(\% 4,5)$ Ev Hanımı $(\% 4)$ ve Doktor (\%3)'dur. Araştırmaya katılanların aylık ortalama gelir düzeylerine bakıldığında, \% 31,50'lik oranla 1601-3200 TL gelir sahibinin en büyük grubu oluşturduğu görülse de hemen hemen her gelir grubundan katılımc1 görülmektedir.

\subsection{Bağlantısal İstatistik Bulguları}

Bu bölüm üç başlık altında incelenmektedir. Birinci bölümde iki bağımsız değişken arasındaki farklılıkları ölçmek için kullandığımız Mann Whitney-U analizine yönelik bulgular bulunmaktadır. İkinci bölümde ise çoklu bağımsız değişken arasındaki farklılıkları ölçmek için kullandığımız Kruskal Wallis H analizine ilişkin bulgular yer almaktadır. Değişkenin (bağımlı) diğer değişken(ler) (bağımsız) tarafından nasıl açıklandığını belirlemek için kullanılan Regresyon analizi ise üçüncü bölümümüzü oluşturmaktadır. 


\subsection{Değisşkenler Arası Mann Whitney U Analizine İlişkin Bulgular}

Araştırma kapsamında ele alınan demografi ifadelerinden iki değişkene sahip cinsiyet (erkek-kadın) ve medeni durum (evli-bekar) değişkenlerinin hizmet kalitesi ve destinasyon imajına anlamlı farklılıklar ortaya koyup koymadığı Mann Whitney U-Testi ile ortaya konulmuştur.

\subsection{Cinsiyet İle Hizmet Kalitesi ve Destinasyon İmajı Arasındaki Mann Whitney U-Testi}

Araştırmaya katılan ziyaretçilerin hizmet kalitesi ve destinasyon imajı algılama puanlarının cinsiyetler arasındaki ilişkisi Tablo 3'te özetlenmiştir.

Tablo 3. Cinsiyete Göre Hizmet Kalitesi ve Destinasyon İmajı Algılamalarına Yönelik Mann Whitney U-Testi.

\begin{tabular}{|l|c|c|c|c|c|c|}
\hline HIZMET KALITESI & Grup & N & Sıra Ort. & Sıra Top. & U & P \\
\hline \multirow{2}{*}{ Cinsiyet } & Kadın & 163 & $\mathbf{2 0 8 , 7 5}$ & 34025,50 & \multirow{2}{*}{1797} & \multirow{2}{*}{, 236} \\
\cline { 2 - 7 } & Erkek & 237 & 194,83 & 46174,50 & & P \\
\hline \multirow{2}{*}{ DESTINASYON IMMAJI } & Grup & $\mathbf{N}$ & Sira Ort. & Sira Top. & U & \multirow{2}{*}{, 953} \\
\hline
\end{tabular}

Tabloya göre katılımcıların hizmet kalitesi algı düzeyleri cinsiyetlere göre anlamlı farklılık göstermemekte $(\mathrm{p}>0,05)$ ve kadın ziyaretçilerin hizmet kalitesi algı düzeyi erkeklerden biraz daha fazla olduğu saptanmaktadır. Destinasyon imajı algı değişkeni de cinsiyetlere göre anlamlı farklılık göstermemektedir ( $p>0,05)$. Araştırmamıza katılan erkek ziyaretçilerin hizmet kalitesi ortalaması 200,09 iken kadın ziyaretçilerin hizmet kalitesi algı ortalaması 200,78 olarak belirlenmiştir. Tabloya göre kadın katılımcıların hizmet kalitesi algılamaları erkek katılımcılardan çok az bir farkla yüksektir. Bu sonuçlar 1şı̆̆ında araştırmanın "Cinsiyet, turist rehberlerinin hizmet kalitesi algısında istatistikî olarak anlaml farklar ortaya koymaktadır (H16)." hipotezi ile, "Cinsiyet, destinasyon imajı algısında istatistikî olarak anlamlı farklar ortaya koymaktadır (H17)." hipotezi desteklenmemektedir.

\subsection{Medeni Durum İle Hizmet Kalitesi ve Destinasyon İmajı Arasındaki Mann Whitney U-Testi}

Araştırmaya katılan ziyaretçilerin hizmet kalitesi ve destinasyon imajı algılama puanları ile medeni durum arasındaki ilişkisi Tablo 4'te belirtilmiştir.

Tablo 4. Medeni Duruma Göre Hizmet Kalitesi ve Destinasyon İmajı Algılamalarına Yönelik Mann Whitney U-Testi.

\begin{tabular}{|c|c|c|c|c|c|c|}
\hline HIZMET KALİTESI & Grup & $\mathbf{N}$ & Sira Ort. & Sira Top. & $\mathbf{U}$ & $\mathbf{P}$ \\
\hline \multirow{2}{*}{ Medeni Durum } & Evli & 208 & 206,76 & 43006,00 & \multirow{2}{*}{1866} & \multirow{2}{*}{,259 } \\
\hline & Bekâr & 192 & 193,72 & 37194,50 & & \\
\hline DESTINAASYON İMAJI & Grup & $\mathbf{N}$ & Sira Ort. & Sira Top. & $\mathbf{U}$ & $\mathbf{P}$ \\
\hline \multirow{2}{*}{ Medeni Durum } & Evli & 208 & 223,21 & 46428,50 & \multirow{2}{*}{1524} & \multirow{2}{*}{, $000 *$} \\
\hline & Bekâr & 192 & 175,89 & 33771,50 & & \\
\hline
\end{tabular}

Katılımcıların hizmet kalitesi algılama düzeyleri medeni duruma göre anlamlı farklılık göstermemektedir ( $>0,05)$. Buna rağmen tablodaki ortalama sırasına göre, evli katılımcıların hizmet kalitesi algılama puanları, bekâr katılımcılardan fazladır. Ancak katılımcıların destinasyon imajı algılama düzeyleri medeni duruma göre anlamlı farklılık göstermektedir $(\mathrm{p}<0,05)$. Tablodaki ortalama sırasına göre, evli katılımcıların destinasyon imajı algılama puanları, bekar katılımcılardan fazladır. Bu sonuçlar ışığında araştırmanın "Medeni durum, turist rehberlerinin hizmet kalitesi algısında istatistikî olarak anlaml farklar ortaya koymaktadır (H20)." hipotezi desteklenmezken, "Medeni durum, örgütsel bağlılık algısında istatistikî olarak anlamlı farklar ortaya koymaktadır (H21)." hipotezi desteklenmektedir.

\subsection{Değişkenler Arası Kruskal Wallis Analizine İlişkin Bulgular}

Araştırmada bulunan demografi ifadelerinden çoklu değişkene sahip yaş (18-25, 26-33, 34-41, 42-49, 5057, 50-56, 57-64 ve 65 ve üzeri), eğitim durumu (ilköğretim, lise ve dengi, lisans, yüksek lisans ve doktora), meslek (kamu çalışan, kamu yönetici, özel sektör çalışan, özel sektör yönetici, özel sektör işveren, doktor, avukat, serbest meslek, öğrenci, emekli ve ev hanımı) ve aylık ortalama gelir düzeyi (0-1600, 
1601-3200, 3201-4800, 4801-6399 ve 6400 ve üzeri) değişkenlerinin hizmet kalitesi ve destinasyon imajına anlamlı farklılıklar ortaya koyup koymadığı Kruskal Wallis H-Testi ile ortaya konulmuştur.

\subsection{Yaş İle Hizmet Kalitesi ve Destinasyon İmajı Arasındaki Kruskal Wallis H-Testi}

Araştırmamıza katılan ziyaretçilerin hizmet kalitesi ve destinasyon imajı algılama puanlarının yaşları arasındaki ilişkisi Tablo 5'de belirtilmiştir.

Tablo 5: Yaşa Göre Hizmet Kalitesi ve Destinasyon İmajı Algılamalarına Yönelik Kruskal Wallis HTesti.

\begin{tabular}{|c|c|c|c|c|c|c|}
\hline $\begin{array}{l}\text { HİZMET } \\
\text { KALITESİ }\end{array}$ & Grup & $\mathbf{N}$ & Sira Ort. & $\begin{array}{c}\text { Chi- } \\
\text { Square }\end{array}$ & Df & $\mathbf{P}$ \\
\hline \multirow{7}{*}{ Yaş } & $18-25$ & 143 & 174,65 & \multirow{7}{*}{15,558} & \multirow{7}{*}{6} & \multirow{7}{*}{,016* } \\
\hline & $26-33$ & 60 & 219,92 & & & \\
\hline & $34-41$ & 92 & 221,30 & & & \\
\hline & $42-49$ & 44 & 214,48 & & & \\
\hline & $50-56$ & 15 & 246,00 & & & \\
\hline & 57-64 & 16 & 185,81 & & & \\
\hline & 65 ve üzeri & 30 & 185,67 & & & \\
\hline $\begin{array}{l}\text { DESTINNASYON } \\
\text { IMMAJI }\end{array}$ & Grup & $\mathbf{N}$ & Sira Ort. & $\begin{array}{l}\text { Chi- } \\
\text { Square }\end{array}$ & Df & $\mathbf{P}$ \\
\hline \multirow{7}{*}{ Yaş } & $18-25$ & 143 & 176,15 & \multirow{7}{*}{34,995} & \multirow{7}{*}{6} & \multirow{7}{*}{,000* } \\
\hline & $26-33$ & 60 & 226,60 & & & \\
\hline & $34-41$ & 92 & 173,22 & & & \\
\hline & $42-49$ & 44 & 214,81 & & & \\
\hline & $50-56$ & 15 & 275,07 & & & \\
\hline & $\begin{array}{l}57-64 \\
\end{array}$ & 16 & 290,44 & & & \\
\hline & 65 ve üzeri & 30 & 241,80 & & & \\
\hline
\end{tabular}

Tablodaki değerlere göre, katılımcıların yaşlarına göre hizmet kalitesi algılama puanları arasındaki farklılık istatistiksel olarak anlamlıdır ( $\mathrm{p}<0,05)$. Buna göre tablodaki ortalama sırasına göre, 50-56 yaş aralığındaki ziyaretçilerin hizmet kalitesi algı puanı en yüksek, 18-25 yaş aralığındaki ziyaretçilerin ise en düşük olduğu gözlemlenmektedir. Aynı şekilde katılımcıların yaşlarına göre destinasyon imajı algılama puanları arasında farklılık istatistiksel olarak anlamlıdır $(\mathrm{p}<0,05)$. Ortalama sırasına göre, 57-64 yaş aralı̆̆ındaki ziyaretçilerin destinasyon imajı algılama puanı en yüksek, 34-41 yaş aralığına sahip ziyaretçilerin destinasyon imajı algılama puanı ise en düşük olduğu görülmektedir. Bu sonuçlar doğrultusunda araştırmanın "Yaş, turist rehberlerinin hizmet kalitesi algısında istatistikî olarak anlaml farklar ortaya koymaktadır (H18)." hipotezi ile "Yaş, destinasyon imajı algısında istatistikî olarak anlamlı farklar ortaya koymaktadır (H19)." hipotezi desteklenmektedir.

\subsection{Eğitim Durumu ile Hizmet Kalitesi ve Destinasyon İmajı Arasındaki Kruskal Wallis H-Testi}

Araştırmaya katılan ziyaretçilerin hizmet kalitesi ve destinasyon imajı algılama puanları ile eğitim durumu arasındaki ilişkisi Tablo 6'da irdelenmiştir. 
Tablo 6: Eğitim Durumuna Göre Hizmet Kalitesi ve Destinasyon İmajı Algılamalarına Yönelik Kruskal Wallis H-Testi.

\begin{tabular}{|c|c|c|c|c|c|c|}
\hline HIZMET KALITTESI & Grup & $\mathbf{N}$ & Sura Ort. & Chi-Square & df & $\mathbf{P}$ \\
\hline \multirow{5}{*}{ Eğitim Durumu } & İlköğretim & 24 & 187,67 & \multirow{5}{*}{4,418} & \multirow{5}{*}{4} & \multirow{5}{*}{, 352} \\
\hline & Lise ve dengi & 87 & 216,57 & & & \\
\hline & Lisans & 234 & 197,56 & & & \\
\hline & Yüksek Lisans & 34 & 175,63 & & & \\
\hline & Doktora & 21 & 221,67 & & & \\
\hline DESTİNASYON İMAJI & Grup & $\mathbf{N}$ & Sira Ort. & Chi-Square & df & $\mathbf{P}$ \\
\hline \multirow{5}{*}{ Eğitim Durumu } & İlköğretim & 24 & 166,48 & \multirow{5}{*}{3,575} & \multirow{5}{*}{4} & \multirow{5}{*}{,467 } \\
\hline & Lise ve dengi & 87 & 197,01 & & & \\
\hline & Lisans & 234 & 201,19 & & & \\
\hline & Yüksek Lisans & 34 & 213,10 & & & \\
\hline & Doktora & 21 & 225,74 & & & \\
\hline
\end{tabular}

Ziyaretçilerin hizmet kalitesi algılama düzeyleri eğitim durumuna göre anlamlı farklılık ortaya koymamaktadır $(\mathrm{p}>0,05)$. Buna rağmen tablodaki ortalama sırasına göre, doktora eğitim düzeyine sahip ziyaretçilerin hizmet kalitesi algılama puanları diğer eğitim düzeyine sahip ziyaretçilerden fazla olduğu gözlemlenmektedir. Benzer olarak, ziyaretçilerin destinasyon imajı algılama düzeyleri eğitim durumuna göre anlamlı farklılık göstermemektedir ( $\mathrm{p}>0,05)$. Buna karşın tablodaki ortalama sırasına göre yine doktora eğitim düzeyine sahip ziyaretçilerin destinasyon imajı algılama puanı diğer eğitim düzeyine sahip ziyaretçilerden fazladır. Bu sonuçlar ışı̆̆ında araştırmanın "Eğitim durumu, turist rehberlerinin hizmet kalitesi algısında istatistikî olarak anlaml farklar ortaya koymaktadır (H22)." hipotezi ile "Eğitim durumu, destinasyon imajı algisında istatistikî olarak anlaml farklar ortaya koymaktadır (H23)." hipotezi desteklenmemektedir.

\subsection{Meslek İle Hizmet Kalitesi ve Destinasyon İmajı Arasındaki Kruskal Wallis H-Testi}

Tablo 7'de hizmet kalitesi ve destinasyon imajı algılama puanları ile eğitim durumu arasındaki ilişkisi incelenmiştir. 
Tablo 7: Mesleğe Göre Hizmet Kalitesi ve Destinasyon İmajı Algılamalarına Yönelik Kruskal Wallis H-Testi.

\begin{tabular}{|c|c|c|c|c|c|c|}
\hline HIZMET KALİTESI & Grup & $\mathbf{N}$ & Sira Ort. & Chi-Square & df & $\mathbf{P}$ \\
\hline \multirow{11}{*}{ Meslek } & Kamu Çalışan & 37 & 186,74 & \multirow{11}{*}{9,719} & \multirow{11}{*}{10} & \multirow{11}{*}{,465 } \\
\hline & Kamu Yönetici & 24 & 207,52 & & & \\
\hline & Özel Sektör Çalışan & 95 & 204,48 & & & \\
\hline & Özel Sektör Yönetici & 24 & 207,75 & & & \\
\hline & Özel Sektör İşveren & 18 & 230,94 & & & \\
\hline & Doktor & 12 & 225,25 & & & \\
\hline & Avukat & 22 & 222,91 & & & \\
\hline & Serbest Meslek & 20 & 173,25 & & & \\
\hline & Öğrenci & 96 & 178,69 & & & \\
\hline & Emekli & 36 & 220,19 & & & \\
\hline & Ev Hanımı & 16 & 224,25 & & & \\
\hline DESTINASYON İMAJI & Grup & $\mathbf{N}$ & Sira Ort. & Chi-Square & df & $\mathbf{P}$ \\
\hline \multirow{11}{*}{ Meslek } & Kamu Çalışan & 37 & 184,78 & \multirow{11}{*}{41,962} & \multirow{11}{*}{10} & \multirow{11}{*}{, $000 *$} \\
\hline & Kamu Yönetici & 24 & 217,46 & & & \\
\hline & Özel Sektör Çalışan & 95 & 166,19 & & & \\
\hline & Özel Sektör Yönetici & 24 & 170,31 & & & \\
\hline & Özel Sektör İşveren & 18 & 259,67 & & & \\
\hline & Doktor & 12 & 215,83 & & & \\
\hline & Avukat & 22 & 232,36 & & & \\
\hline & Serbest Meslek & 20 & 197,30 & & & \\
\hline & Öğrenci & 96 & 184,58 & & & \\
\hline & Emekli & 36 & 286,64 & & & \\
\hline & Ev Hanımı & 16 & 244,22 & & & \\
\hline
\end{tabular}

Tablodaki değerlere göre, katılımcıların mesleklerine göre hizmet kalitesi algılama puanları istatistiksel olarak anlamlı farklılıklar göstermemektedir $(\mathrm{p}>0,05)$. Buna göre tablodaki ortalama sırasına göre özel sektör işverenlerin hizmet kalitesi algılama puanı en yüksek, serbest meslek erbabı ziyaretçilerin ise en düşük olduğu gözlemlenmektedir. Ancak katılımcıların meslekleri ile destinasyon imajı algılama puanları arasındaki farklılık, istatistiksel olarak anlamlıdır $(\mathrm{p}<0,05)$. Ortalama sırasına göre, emekli ziyaretçilerin destinasyon imajı algılama puanı en yüksek, özel sektör çalışanı olan ziyaretçilerin ise destinasyon imajı algılama puanı en düşük olduğu görülmektedir. Bu sonuçlar doğrultusunda araştırmanın "Melek, turist rehberlerinin hizmet kalitesi algısında istatistikî olarak anlaml farklar ortaya koymaktadır (H24)." hipotezi desteklenmezken "Meslek, destinasyon imajı algısında istatistikî olarak anlamlı farklar ortaya koymaktadır (H25)." hipotezi desteklenmektedir.

\subsection{Aylık Ortalama Gelir Düzeyi İle Hizmet Kalitesi ve Destinasyon İmajı Arasındaki Kruskal Wallis H-Testi}

Aylık ortalama gelir düzeyi, hizmet kalitesi ve destinasyon imajı algılamalarında anlamlı farkların ortaya koyup koymadığı Tablo 8'de belirtilmiştir. 
Tablo 8: Aylık Ortalama Gelir Düzeyine Göre Hizmet Kalitesi ve Destinasyon İmajı Algılamalarına Yönelik Kruskal Wallis H-Testi.

\begin{tabular}{|c|c|c|c|c|c|c|}
\hline HIZMET KALİTESI & Grup & $\mathbf{N}$ & Sura Ort. & Chi-Square & df & $\mathbf{P}$ \\
\hline \multirow{5}{*}{$\begin{array}{l}\text { Aylık Ortalama } \\
\text { Gelir Düzeyi }\end{array}$} & $0-1600 \mathrm{TL}$ & 102 & 178,30 & \multirow{5}{*}{6,636} & \multirow{5}{*}{4} & \multirow{5}{*}{, 156} \\
\hline & $1601-3200 \mathrm{TL}$ & 126 & 211,64 & & & \\
\hline & 3201-4800 TL & 92 & 196,64 & & & \\
\hline & 4801-6399 TL & 46 & 220,67 & & & \\
\hline & 6400 TL ve üstü & 34 & 208,96 & & & \\
\hline DESTINASYON İMAJI & Grup & $\mathbf{N}$ & Sira Ort. & Chi-Square & df & $\mathbf{P}$ \\
\hline \multirow{5}{*}{$\begin{array}{l}\text { Aylık Ortalama } \\
\text { Gelir Düzeyi }\end{array}$} & $0-1600 \mathrm{TL}$ & 102 & 181,68 & \multirow{5}{*}{22,737} & \multirow{5}{*}{4} & \multirow{5}{*}{, $000 *$} \\
\hline & $1601-3200 \mathrm{TL}$ & 126 & 197,31 & & & \\
\hline & $3201-4800 \mathrm{TL}$ & 92 & 179,57 & & & \\
\hline & 4801-6399 TL & 46 & 252,07 & & & \\
\hline & 6400 TL ve üstü & 34 & 255,66 & & & \\
\hline
\end{tabular}

Katılımcıların hizmet kalitesi ve destinasyon imajı algılama puanlarının aylık ortalama gelir düzeyi arasındaki ilişkisine baktığımızda, ziyaretçilerin hizmet kalitesi algılama düzeyleri aylık ortalama gelir düzeyine göre anlamlı farklılık göstermemektedir $(\mathrm{p}>0,05)$. Buna rağmen tablodaki ortalama sırasına göre, 4801-6399 TL gelir düzeyine sahip katılımcıların hizmet kalitesi algılama puanı diğer gelir düzeyine katılımcılardan fazladır. Ancak katılımcıların destinasyon imajı algılama düzeyleri aylık ortalama gelir düzeyine göre anlamlı farkl1lık göstermektedir $(\mathrm{p}<0,05)$. Tablodaki ortalama sirasına göre, $6400 \mathrm{TL}$ ve üstü aylık ortalama gelir düzeyine sahip katılımcıların destinasyon imajı algılama puanları diğer gelir düzeyine sahip katılımcılardan fazladır. Bu sonuçlar ışı̆̆ında araştırmanın "Aylık ortalama gelir düzeyi, turist rehberlerinin hizmet kalitesi algısında istatistikî olarak anlaml farklar ortaya koymaktadır (H26)." hipotezi desteklenmezken, "Aylık ortalama gelir düzeyi, destinasyon imajı algısında istatistikî olarak anlamlı farklar ortaya koymaktadır (H27)." hipotezi desteklenmektedir.

\subsection{Değişkenler Arası Regresyon Analizine İliş̧kin Bulgular}

Araştırma modeline göre bağımlı değişken olan destinasyon imaji ve alt boyutlarının etkilediği varsayılan bağımsız değişken hizmet kalitesi ve alt boyutlarıdır. Çalışma kapsamında ele alınan iki temel değişken ve alt boyutları arasındaki etkilere yönelik istatistiki sonuçlar regresyon analizi sonuçlarıyla belirtilmiştir. Geliştirilen hipotezler çoklu regresyon analiziyle test edilmiş ve sonuçlar aşağıda verilmiştir.

\subsection{Hizmet Kalitesinin Somut Ögeler Alt Boyutunun Destinasyon İmajı Alt Boyutları Üzerindeki} Etkisine Yönelik Regresyon Analizi

Regresyon analizi sonucunda bağımsız değişken hizmet kalitesinin somut ögeler alt boyutu ile bağımlı değişken destinasyon imajının alt boyutları arasında belirlenen etkinin niteliği bu bölümde açıklanmıştır. $\mathrm{Bu}$ amaçla gerçekleştirilen regresyon analizi sonuçları Tablo 9' da belirtilmiştir.

Tablo 9: Hizmet Kalitesinin Somut Ögeler Alt Boyutunun Destinasyon İmajı Alt Boyutları Üzerindeki Etkisine Yönelik Regresyon Analizi

\begin{tabular}{|c|c|c|c|c|c|}
\hline Model 1 & $\mathbf{R}^{2}$ & $\mathbf{F}$ & Std. Edilmiş Beta & $\mathbf{t}$ & Anlamlılık (P) \\
\hline Somut Ögeler &, 156 & 73,757 & 396 & 8,588 &, $000 *$ \\
\hline \multicolumn{6}{|c|}{ Bağımlı Değișken: Duygusal İmaj } \\
\hline Model 2 & $\mathbf{R}^{\mathbf{2}}$ & $\mathbf{F}$ & Std. Edilmiş Beta & $\mathbf{t}$ & Anlamlılık (P) \\
\hline Somut Ögeler & ,222 & 113,355 & ,471 & 10,647 &, $000 *$ \\
\hline \multicolumn{6}{|c|}{ Bağımlı Değişken: Bilişsel İmaj } \\
\hline Model 3 & $\mathbf{R}^{2}$ & $\mathbf{F}$ & Std. Edilmiş Beta & $\mathbf{t}$ & Anlamlılık (P) \\
\hline Somut Ögeler & 053 & 22,392 & 231 & 4,732 &, $000 *$ \\
\hline
\end{tabular}

Model 1 kapsamında yapılan regresyon analizi sonucunda somut ögeler ve duygusal imaj arasında kurulan modelin anlamlı olduğu $(\mathrm{P}$ değeri=0,000<0,05) ve somut ögeler duygusal imajı etkilediği gözlemlenmektedir. 
Bu etki pozitif yönde bir etkiye sahiptir. Somut Ögeler değişkeni, duygusal imajı \% 15,6 olarak açıklamaktadır $\left(\mathrm{R}^{2}=0,156\right)$. Model 1 testi sonucuna göre çalışmanın "Turist rehberlerinin algilanan hizmet kalitesinin somut öğeleri boyutu, duygusal destinasyon imajı algısında pozitif ve anlamlı düzeyde etkilidir (H1.1)" hipotezi desteklenmektedir.

Model 2 kapsamında yapılan regresyon analizi sonucunda somut ögeler ve bilişsel imaj arasında kurulan modelin anlamlı olduğu $(\mathrm{P}$ değeri $=0,000<0,05)$ görülmektedir. Somut ögeler bilişsel imajı etkilemekte ve bu etkinin pozitif yönde olduğu gözlemlenmektedir. Yapısal sermaye değişkeni, iş tatminini \% 22,2 olarak açıklamaktadır $\left(\mathrm{R}^{2}=0,222\right)$. Model 2 testi sonucuna göre çalışmanın "Turist rehberlerinin algılanan hizmet kalitesinin somut öğeleri boyutu, bilişsel destinasyon imajı algısında pozitif ve anlamlı düzeyde etkilidir (H1.2)" hipotezi desteklenmektedir.

Model 3 kapsamında yapılan regresyon analizi sonucunda somut ögeler ve genel imaj arasında kurulan model anlamlıdır ( $\mathrm{P}$ değeri $=0,000<0,05)$. Yine somut ögeler, genel imajı pozitif yönde etkilemekte ve somut ögeler değişkeni, genel imaj1 \% 5,3 olarak açıklamaktadır $\left(\mathrm{R}^{2}=0,053\right)$. Model 3 testi sonucuna göre çalışmanın "Turist rehberlerinin algılanan hizmet kalitesinin somut ögeler boyutu, genel destinasyon imajı algisinda pozitif ve anlamlı düzeyde etkilidir (H1.3)" hipotezi desteklenmektedir.

\subsection{Hizmet Kalitesinin Güvenilirlik Alt Boyutunun Destinasyon İmajı Alt Boyutları Üzerindeki Etkisine Yönelik Regresyon Analizi}

Bağımsız değişken hizmet kalitesinin güvenilirlik alt boyutu ile bağımlı değişken destinasyon imajının alt boyutları arasında belirlenen etkinin niteliği aşağıda açıklanmıştır. Bu amaçla gerçekleştirilen regresyon analizi sonuçları Tablo 10'da belirtilmiştir.

Tablo 10: Hizmet Kalitesinin Güvenilirlik Alt Boyutunun Destinasyon İmajı Alt Boyutları Üzerindeki Etkisine Yönelik Regresyon Analizi

\begin{tabular}{|c|c|c|c|c|c|}
\hline Model 4 & $\mathbf{R}^{2}$ & $\mathbf{F}$ & Std. Edilmiş Beta & $\mathbf{t}$ & Anlamlılık (P) \\
\hline Güvenilirlik & ,173 & 83,447 & ,416 & 9,135 &, $000 *$ \\
\hline \multicolumn{6}{|c|}{ Bağımlı Değişken: Duygusal İmaj } \\
\hline Model 5 & $\mathbf{R}^{2}$ & $\mathbf{F}$ & Std. Edilmiş Beta & $\mathbf{t}$ & Anlamlılık (P) \\
\hline Güvenilirlik & 255 & 135,885 &, 505 & 11,657 &, $000 *$ \\
\hline \multicolumn{6}{|c|}{ Bağımlı Değişken: Bilişsel İmaj } \\
\hline Model 6 & 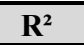 & $\overline{\mathbf{F}}$ & "Std. Edilmiş Beta & 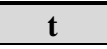 & Anlamlılık (P) \\
\hline Güvenilirlik &, 110 & 49,030 & 331 & 7,002 &, $000 *$ \\
\hline
\end{tabular}

Model 4 kapsamında yapılan regresyon analizi sonucunda güvenilirlik ve duygusal imaj arasında kurulan modelin anlamlı olduğu (P değeri=0,000<0,05) ve güvenilirlik, duygusal imaj1 etkilediği gözlemlenmektedir. $\mathrm{Bu}$ etki pozitif yönde bir etkiye sahiptir. Güvenilirlik değişkeni, duygusal imaj1 \% 17,3 olarak açıklamaktadır $\left(\mathrm{R}^{2}=0,173\right)$. Model 4 testi sonucuna göre çalışmanın "Turist rehberlerinin algılanan hizmet kalitesinin güvenilirlik boyutu, duygusal destinasyon imajı algısında pozitif ve anlamlı düzeyde etkilidir (H1.4)" hipotezi desteklenmektedir.

Model 5 kapsamında yapılan regresyon analizi sonucunda güvenilirlik ve bilişsel imaj arasında kurulan modelin anlamlı olduğu (P değeri=0,010<0,05) görülmektedir. Güvenilirlik, bilişsel imajı etkilemekte ve bu etkinin pozitif yönde olduğu gözlemlenmektedir. Yapısal sermaye değişkeni, iş tatminini \% 25,5 olarak açıklamaktadır $\left(\mathrm{R}^{2}=0,255\right)$. Model 5 testi sonucuna göre çalışmanın "Turist rehberlerinin algılanan hizmet kalitesinin güvenilirlik boyutu, bilişsel destinasyon imajı algısında pozitif ve anlamlı düzeyde etkilidir (H1.5)" hipotezi desteklenmektedir.

Model 6 kapsamında yapılan regresyon analizi sonucunda güvenilirlik ve genel imaj arasında kurulan model anlamlıdır ( $\mathrm{P}$ değeri $=0,000<0,05)$. Yine güvenilirlik, genel imaj1 pozitif yönde etkilemekte ve güvenilirlik değişkeni, genel imajı \%11 olarak açıklamaktadır $\left(\mathrm{R}^{2}=0,110\right)$. Model 6 testi sonucuna göre çalışmanın "Turist rehberlerinin algılanan hizmet kalitesinin güvenilirlik boyutu, genel destinasyon imaj1 algısında pozitif ve anlamlı düzeyde etkilidir (H1.6)" hipotezi desteklenmektedir. 


\subsection{Hizmet Kalitesinin Empati Alt Boyutunun Destinasyon İmajı Alt Boyutları Üzerindeki Etkisine Yönelik Regresyon Analizi}

Yapılan analiz sonucunda bağımsız değişken hizmet kalitesinin empati alt boyutu ile bağımlı değişken destinasyon imajının alt boyutları arasında belirlenen etkinin niteliği bu bölümde açıklanmıştır. Bu amaçla gerçekleştirilen regresyon analizi sonuçları Tablo 11'de belirtilmiştir.

Tablo 11: Hizmet Kalitesinin Empati Alt Boyutunun Destinasyon İmajı Alt Boyutları Üzerindeki Etkisine Yönelik Regresyon Analizi

\begin{tabular}{|l|c|c|c|c|c|}
\hline Model 7 & $\mathbf{R}^{\mathbf{2}}$ & $\mathbf{F}$ & Std. Edilmiş Beta & $\mathbf{t}$ & Anlamlılık (P) \\
\hline Empati &, 040 & 16,626 &, 200 & 4,078 & $\mathbf{, 0 0 0}^{*}$ \\
\hline Bağımlı Değişken: Duygusal İmaj & \multicolumn{5}{|l|}{} \\
\hline Model 8 & $\mathbf{R}^{\mathbf{2}}$ & $\mathbf{F}$ & Std. Edilmiş Beta & $\mathbf{t}$ & Anlamlılık (P) \\
\hline Empati &, 092 & 40,294 &, 303 & 6,348 & $\mathbf{0 0 0}^{*}$ \\
\hline Bağımlı Değişken: Bilişssel İmaj & \multicolumn{5}{|l|}{} \\
\hline Model 9 & $\mathbf{R}^{\mathbf{2}}$ & $\mathbf{F}$ & Std. Edilmiş Beta & $\mathbf{t}$ & Anlamlılık (P) \\
\hline Empati &, 035 & 14,572 &, 188 & 3,817 & $\mathbf{0 0 0}^{*}$ \\
\hline Bağımlı Değişken: Genel İmaj
\end{tabular}

Model 7 kapsamında yapılan regresyon analizi sonucunda empati ve duygusal imaj arasında kurulan modelin anlamlı olduğu $(\mathrm{P}$ değeri $=0,000<0,05)$ ve empati, duygusal imaj1 etkilediği gözlemlenmektedir. $\mathrm{Bu}$ etki pozitif yönde bir etkiye sahiptir. Empati değişkeni, duygusal imajı $\% 4$ olarak açıklamaktadır $\left(\mathrm{R}^{2}=0,040\right)$. Model 7 testi sonucuna göre çalışmanın "Turist rehberlerinin algllanan hizmet kalitesinin empati boyutu, duygusal destinasyon imajı algısında pozitif ve anlaml düzeyde etkilidir (H1.7)" hipotezi desteklenmektedir.

Model 8 kapsamında yapılan regresyon analizi sonucunda empati ve bilişsel imaj arasında kurulan modelin anlamlı olduğu (P değeri=0,010<0,05) görülmektedir. Empati, bilişsel imajı etkilemekte ve bu etkinin pozitif yönde olduğu gözlemlenmektedir. Yapısal sermaye değişkeni, iş tatminini \% 9,2 olarak açıklamaktadır $\left(\mathrm{R}^{2}=0,092\right)$. Model 8 testi sonucuna göre çalışmanın "Turist rehberlerinin algılanan hizmet kalitesinin empati boyutu, bilişsel destinasyon imajı algısında pozitif ve anlaml düzeyde etkilidir (H1.8)" hipotezi desteklenmektedir.

Model 9 kapsamında yapılan regresyon analizi sonucunda empati ve genel imaj arasında kurulan model anlamlıdır ( $\mathrm{P}$ değeri=0,000<0,05). Yine empati, genel imajı pozitif yönde etkilemekte ve empati değişkeni, genel imaj1 \% 3,5 olarak açıklamaktadır $\left(\mathrm{R}^{2}=0,035\right)$. Model 9 testi sonucuna göre çalışmanın "Turist rehberlerinin algllanan hizmet kalitesinin empati boyutu, genel destinasyon imajı algisinda pozitif ve anlaml düzeyde etkilidir (H1.9)" hipotezi desteklenmektedir.

\subsection{Hizmet Kalitesinin İsteklilik Alt Boyutunun Destinasyon İmajı Alt Boyutları Üzerindeki} Etkisine Yönelik Regresyon Analizi

Regresyon analizi sonucunda bağımsız değişken hizmet kalitesinin isteklilik alt boyutu ile bağımlı değişken destinasyon imajının alt boyutları arasında belirlenen etkinin niteliği bu bölümde açıklanmıştır. Bu amaçla gerçekleştirilen regresyon analizi sonuçları Tablo 12'de belirtilmiştir.

Tablo 12: Hizmet Kalitesinin İsteklilik Alt Boyutunun Destinasyon İmajı Alt Boyutları Üzerindeki Etkisine Yönelik Regresyon Analizi

\begin{tabular}{|l|c|c|c|c|c|}
\hline Model 10 & $\mathbf{R}^{\mathbf{2}}$ & $\mathbf{F}$ & Std. Edilmiş Beta & $\mathbf{t}$ & Anlamlılık (P) \\
\hline İsteklilik &, 020 & 8,205 & $\mathbf{- , 1 4 2}$ & $\mathbf{- 2 , 8 6 4}$ & $\mathbf{, 0 0 4}$ \\
\hline Bağımlı Değişken: Duygusal İmaj & \multicolumn{5}{|l|}{} \\
\hline \hline Model 11 & $\mathbf{R}^{\mathbf{2}}$ & $\mathbf{F}$ & Std. Edilmiş Beta & $\mathbf{t}$ & Anlamlılık (P) \\
\hline İsteklilik &, 035 & 14,398 & $\mathbf{- , 1 8 7}$ & $\mathbf{- 3 , 7 9 4}$ & $\mathbf{0 0 0}^{*}$ \\
\hline Bağımlı Değişken: Bilişsel İmaj & \multicolumn{5}{|l|}{} \\
\hline Model 12 & $\mathbf{R}^{\mathbf{2}}$ & $\mathbf{F}$ & Std. Edilmiş Beta & $\mathbf{t}$ & Anlamlılık (P) \\
\hline İsteklilik &, 075 & 32,075 & $\mathbf{- , 2 7 3}$ & $\mathbf{- 5 , 6 6 4}$ &, $\mathbf{0 0 0} *$ \\
\hline Bağımlı Değişken: Genel &
\end{tabular}


Model 10 kapsamında yapılan regresyon analizi sonucunda isteklilik ve duygusal imaj arasında kurulan model anlamlıdır ( $\mathrm{P}$ değeri=0,004<0,05). Ancak isteklilik, duygusal imaj1 negatif yönde etkilediği gözlemlenmektedir ve \% 2 olarak açıklamaktadır $\left(\mathrm{R}^{2}=0,020\right)$. Model 10 testi sonucuna göre çalışmanın "Turist rehberlerinin algılanan hizmet kalitesinin isteklilik boyutu, duygusal destinasyon imajı algisinda pozitif ve anlamlı düzeyde etkilidir (H1.10)" hipotezi anlamlılık bakımından desteklense de negatif yönde etkilediği için doğrulanmamaktadır.

Model 11 kapsamında yapılan regresyon analizi sonucunda isteklilik ve bilişsel imaj arasında kurulan modelin anlamlı olduğu görülmektedir (P değeri $=0,000<0,05)$. İsteklilik, bilişsel imajı, negatif pozitif yönde etkilediği gözlemlenmektedir ve isteklilik değişkeni, bilişsel imaj1 \% 3,5 olarak açıklamaktadır $\left(\mathrm{R}^{2}=0,035\right)$. Model 11 testi sonucuna göre çalışmanın "Turist rehberlerinin algılanan hizmet kalitesinin isteklilik boyutu, bilişsel destinasyon imajı algısında pozitif ve anlamlı düzeyde etkilidir (H1.11)" hipotezi anlamlılık bakımından desteklense de negatif yönde etkilediği için doğrulanmamaktadır.

Model 12 kapsamında yapılan regresyon analizi sonucunda isteklilik ve genel imaj arasında kurulan model anlamlıdır ( $\mathrm{P}$ değeri $=0,000<0,05)$. Yine isteklilik, genel imajı negatif yönde etkilemekte ve $\% 7,5$ olarak açıklamaktadır $\left(\mathrm{R}^{2}=0,075\right)$. Model 12 testi sonucuna göre çalışmanın "Turist rehberlerinin algılanan hizmet kalitesinin isteklilik boyutu, genel destinasyon imajı algısında pozitif ve anlamlı düzeyde etkilidir (H1.12)" hipotezi anlamlılık bakımından desteklense de negatif yönde etkilediği için doğrulanmamaktadır.

\subsection{Hizmet Kalitesinin Güvence Alt Boyutunun Destinasyon İmajı Alt Boyutları Üzerindeki Etkisine Yönelik Regresyon Analizi}

Bağımsız değişken hizmet kalitesinin güvenilirlik alt boyutu ile bağımlı değişken destinasyon imajının alt boyutları arasında belirlenen etkinin niteliği aşağıda açıklanmıştır. $\mathrm{Bu}$ amaçla gerçekleştirilen regresyon analizi sonuçları Tablo 13'te belirtilmiştir.

Tablo 13: Hizmet Kalitesinin Güvence Alt Boyutunun Destinasyon İmajı Alt Boyutları Üzerindeki Etkisine Yönelik Regresyon Analizi

\begin{tabular}{|l|c|c|c|c|c|}
\hline Model 13 & $\mathbf{R}^{\mathbf{2}}$ & $\mathbf{F}$ & Std. Edilmiş Beta & $\mathbf{t}$ & Anlamlılık (P) \\
\hline Güvence &, 214 & 108,353 &, 463 & 10,409 & $\mathbf{, 0 0 0}^{*}$ \\
\hline Bağımlı Değişken: Duygusal İmaj & \multicolumn{5}{|l|}{} \\
\hline Model 14 & $\mathbf{R}^{\mathbf{2}}$ & $\mathbf{F}$ & Std. Edilmiş Beta & $\mathbf{t}$ & Anlamlılık (P) \\
\hline Güvence &, 267 & 144,763 &, 516 & 12,032 & $\mathbf{, 0 0 0}^{*}$ \\
\hline Bağımlı Değişken: Bilişsel İmaj \\
\hline Model 15 & $\mathbf{R}^{\mathbf{2}}$ & $\mathbf{F}$ & Std. Edilmiş Beta & $\mathbf{t}$ & Anlamlılık (P) \\
\hline Güvence &, 076 & 32,664 &, 275 & 5,715 &, $\mathbf{0 0 0 *}$ \\
\hline Bağımlı Değişken: Genel İmaj
\end{tabular}

Model 13 kapsamında yapılan regresyon analizi sonucunda güvence ve duygusal imaj arasında kurulan modelin anlamlı olduğu ( $\mathrm{P}$ değeri=0,000<0,05) ve güvence, duygusal imaj1 etkilediği gözlemlenmektedir. $\mathrm{Bu}$ etki pozitif yönde bir etkiye sahiptir. Güvence değişkeni, duygusal imajı \% 21,4 olarak açıklamaktadır $\left(\mathrm{R}^{2}=0,214\right)$. Model 13 testi sonucuna göre çalışmanın "Turist rehberlerinin algllanan hizmet kalitesinin güvence boyutu, duygusal destinasyon imajı algısında pozitif ve anlamlı düzeyde etkilidir (H1.13)" hipotezi desteklenmektedir.

Model 14 kapsamında yapılan regresyon analizi sonucunda güvence ve bilişsel imaj arasında kurulan modelin anlamlı olduğu (P değeri $=0,000<0,05)$ görülmektedir. Güvence, bilişsel imaj1 etkilemekte ve bu etkinin pozitif yönde olduğu gözlemlenmektedir. Yapısal sermaye değişkeni, iş tatminini \% 26,7 olarak açıklamaktadır $\left(\mathrm{R}^{2}=0,267\right)$. Model 14 testi sonucuna göre çalışmanın "Turist rehberlerinin algılanan hizmet kalitesinin güvence boyutu, bilişsel destinasyon imajı algısında pozitif ve anlamlı düzeyde etkilidir (H1.14)" hipotezi desteklenmektedir.

Model 15 kapsamında yapılan regresyon analizi sonucunda güvence ve genel imaj arasında kurulan model anlamlıdır ( $\mathrm{P}$ değeri $=0,000<0,05)$. Yine güvence, genel imaj1 pozitif yönde etkilemekte ve güvence değişkeni, genel imajı \% 7,6 olarak açıklamaktadır $\left(\mathrm{R}^{2}=0,076\right)$. Model 15 testi sonucuna göre çalışmanın "Turist rehberlerinin algilanan hizmet kalitesinin güvence boyutu, genel destinasyon imajı algisinda pozitif ve anlamlı düzeyde etkilidir (H1.15)" hipotezi desteklenmektedir. 


\subsection{Hizmet Kalitesinin Destinasyon İmajı Üzerindeki Etkisine Yönelik Regresyon Analizi}

Yapılan analiz sonucunda bağımsız değişken hizmet kalitesinin bağımlı değişken destinasyon imajı arasında belirlenen etkinin niteliği bu bölümde açıklanmıştır. Bu amaçla gerçekleştirilen regresyon analizi sonuçları Tablo 14'te belirtilmiştir.

Tablo 14: Hizmet Kalitesinin Destinasyon İmajı Üzerindeki Etkisine Yönelik Regresyon Analizi

\begin{tabular}{|l|c|c|c|c|c|}
\hline Model 16 & $\mathbf{R}^{\mathbf{2}}$ & $\mathbf{F}$ & Std. Edilmiş Beta & t & Anlamlılık (P) \\
\hline Hizmet Kalitesi &, 192 & 94,279 &, 438 & 9,710 & $\mathbf{, 0 0 0}^{*}$ \\
\hline
\end{tabular}

Model 16 kapsamında yapılan regresyon analizi sonucunda hizmet kalitesi ve destinasyon imajı arasında kurulan modelin anlamlı olduğu ( $\mathrm{P}$ değeri $=0,000<0,05)$ ve hizmet kalitesi, destinasyon imajını etkilediği gözlemlenmektedir. Bu etki pozitif yönde bir etkiye sahiptir. Hizmet kalitesi değişkeni, destinasyon imajını \% 19,2 olarak açıklamaktadır $\left(\mathrm{R}^{2}=0,192\right)$. Model 16 testi sonucuna göre çalışmanın ana hipotezi olan "Turist rehberlerinin hizmet kalitesinin destinasyon imajına etkisi vardır. (H1)" hipotezi desteklenmektedir.

\section{SONUC}

Turizm genellikle bir ülkenin ekonomik gelişimine büyük katkıda bulunur ve Türkiye de bu konuda istisna değildir. Birçok araştırmac1, turist deneyiminin öncüsü olarak turist rehberlerini önemli görmektedir. Rehberlerin hangi role bürünmeleri ve turistlerin deneyimlerini nasıl kolaylaştırmaları gerektiği konusunda farklı açıklamalar yapmışlardır. Tur rehberleri kültür elçileri olarak aracılık edebilecek durumda olduklarından dolayı, turistler tarafindan yorumlamalara da maruz kalmaktadır. Dolayısıyla, turist rehberlerinin yaşadığı şey, bir bakıma toplu tüketim için metalaştırılan turistlerin öznel ve tekrarlanan yorumlamalarıdır. Bir kültürel yapının doğru yorumlanması ile kültürel değişkenin övülen ekspresyonu arasında ince bir ayrım vardır. Devlet tarafindan desteklenen tur rehberi eğitim programları, sıklıkla girdiler sağlamakta ve destinasyon için turist rehberlerinden bir nevi satış görevlileri hazırlamaktadır. Türkiye, ulusal önemi olan konuları ele almak veya geliştirmek için turizmi stratejik olarak kullanmalı ve istenen ulusal kimliği bu sayede geliştirmelidir.

Bir destinasyonu ziyaret eden turistler için tur rehberlerinin önemi kaliteli turizm tecrübesi için göz ardı edilemez. Turizm yöneticileri ve organizasyonları, destinasyonların rekabetinde, rehberleri kolaylaştırıcı etken olarak görmektedir. Bunun gerçekleşmesi de, rehberlere yardımcı olan bir çalışma ortamı yaratılmasına bağlıdır. İş yaşamının kalitesinin yükselmesi, iş tatmini seviyesinin artması, paydaşlarla olan iyi ilişkiler ve işten zevk alınması, rehberlik mesleğinin kolaylaştırılması için gereken konular arasındadır.

Turistin hoş bir deneyim kazanması için daha fazla etkin rehber olması gerekmektedir. Çünkü onlar, yerel halkın tanıtılmasında turist ile ev sahibi topluluğu arasındaki sosyal etkileşimi sağlayan arabulucudur. Öte yandan, rehberlerin turistleri zarara uğratıp koruyamadıkları ve bu süreçte "gerçeklikten" ve "otantik tecrübe" den de mahrum bıraktıkları zamanlar yok değildir. Kostümlü mütercimlerin, tarihi yerlerde geçmiş atmosferi ve geçmişi hissetmeyi başarabildikleri, ancak yeterli öğrenmeyi sağlayamadıkları da söylenebilir. Tur rehberinin anlatı ve yorumlarını, kendi gündemlerinin sosyo-kültürel, tarihi ve siyasal bağlamlarına ya da istihdam koşullarına dayandırması nedeniyle önyargılı davranabileceği de belirtilmelidir. Bir tur rehberinin yorumlarının toplum kurallarına uygun anlatılar olmama riski de vardır. Ayrıca, kendi kendine hizmet edebilirler. Tur şirketlerini temsil eden birçok tur rehberinin, turistleri belirli satıcılara yönlendirmeleri beklenir ve bu şirketler, onlardan komisyon almaktadır.

Ülkedeki seyahat acenteleri tarafından tasarlanan ve desteklenen rehberli turların niteliğinden ve sayısından ülke imajı etkilenebilir. Olumsuz bir görüntü, destinasyonun çekiciliğini, bir bileşenden duyulan memnuniyetsizlik destinasyonun genel olarak olumsuz bir şekilde değerlendirilmesine neden olabilmektedir. Dolayısıyla, turizmde destinasyon imajını geliştirme, turistler için bir turizm bölgesi olarak konumlandırma ve farklılaştırma için rehberli turlar, turist rehberi ve onun hizmet kalitesi etkin bir role sahiptir. Ayrıca, bu yönde yapılan çalışmalar, turist rehberinin hizmet kalitesi ve destinasyon imajı hakkındaki görüşlerini etkileyecek olan unsurun rehberli tura katılan turistlerin memnuniyeti olduğu yönündedir.

Turizm araştırmalarında literatürde turist memnuniyeti ve destinasyon sadakati büyük ilgi görmüştür ve bu konularla alakalı birç̧ok araştırma yürütülmüştür. $\mathrm{Bu}$ araştırmalardaki bilgi boşluğu, özellikle turist rehberlerinin hizmet kalitesi ve destinasyon imajını etkileyici bir faktör olarak gözetilmeden araştırmaların çoğunlukla dışında bırakılmış olmasıdır. Halbuki, turizm araştırmalarında turist rehberine, onun hizmet kalitesine, tekrar ziyarette ve destinasyona olan sadakatte destinasyon imajının önemine vurgu yapılması bir ihtiyaç olmalıdır. Bahsedilen bilgi boşluğunun üstesinden gelmek ve bir katkı sağlamak amacıyla, bu çalışma, 
turist memnuniyeti ve destinasyon sadakatini sağlayan yan unsurlara yani, destinasyon imajına katkı sağlayan turist rehberlerinin hizmet kalitesi perspektifine odaklanmıştır.

Turizm alanında turist rehberi, hizmet kalitesi ve destinasyon imajı arasındaki etki ve ilişkilerin incelendiği araştırmalar yol gösterici olmakta ve gerekli enformasyonlar sağlamaktadır. Literatürde bahsedilen kavramların ehemmiyetinden yola çıkılarak, destinasyon imajının sağlanmasında turist rehberlerinin ve onların hizmet kalitelerinin etkisi Konya'da araştırılmaya çalışılmıştır. Dahası, katılımcıların demografik özelliklerinin turist rehberlerinin hizmet kalitesi ve destinasyon imajı üzerinde istatistikî olarak anlamlı farklar ortaya çıkarıp çıkarmadığı da incelenmiştir. Konya'yı ziyaret edenlere yönelik uygulanan anket vasıtasıyla önemli bir takım bulgulara ulaşılmıştır.

Demografik ifade ve ölçek alt boyutları arasındaki Mann Whitney U analizlerine baktığımızda, katılımcıların hizmet kalitesi ve destinasyon imajı algı düzeyleri cinsiyetlere göre anlamlı farklılık göstermediği ortaya çıkmıştır. Kadın ziyaretçilerin hizmet kalitesi ve destinasyon imajı algı düzeyi erkeklerden biraz daha fazla olduğu saptanmıştır. Medeni durumda ise, katılımcıların hizmet kalitesi algılama düzeyleri anlamlı farklılık göstermediği gözlemlenmiştir. Ancak, destinasyon imajı algılama düzeyleri medeni duruma göre anlamlı farklılık göstermektedir. Bu bilgilere ek olarak, evli katılımcıların hizmet kalitesi ve destinasyon imajı algılama puanları, bekar katılımcılardan fazla olduğu ortaya çıkmıştır.

Kruskal Wallis $\mathrm{H}$ analizlerinde ise, katılımcıların hizmet kalitesi ve destinasyon imajı algı düzeyleri yaşa göre anlamlı farklılık gösterirken, eğitim durumuna göre anlamlı farkl1lık göstermemiştir. 50-56 yaş aralığındaki katılımcıların hizmet kalitesinin ve 57-64 yaş aralığındaki katılımcıların destinasyon imajının algılama düzeyleri diğer yaş aralığındaki katılımcılara istinaden fazla olduğu, doktora eğitim düzeyine sahip katılımcıların hem hizmet kalitesi ve hem de destinasyon imajı alg1 düzeyi diğer eğitim düzeylerine sahip katılımcılara istinaden fazla olduğu belirlenmiştir.

Katılımcıların hizmet kalitesi algı düzeyleri mesleğe ve aylık ortalama gelir düzeyine göre anlamlı farklılık göstermezken, eğitim durumuna göre destinasyon imajı algı düzeyleri mesleğe ve aylık ortalama gelir düzeyine göre anlamlı farklılık gösterdiği gözlemlenmiştir. Özel sektördeki işverenlerin hizmet kalitesi, emeklilerin ise destinasyon imajı alg1 düzeyi diğer meslek gruplarına sahip katılımcılara göre fazla olduğu; 4801-6399 TL gelir düzeyine sahip katılımcıların hizmet kalitesi, 6400 TL ve üstü gelir düzeyine sahip katılımcıların ise destinasyon imajı algı düzeyi diğer eğitim düzeylerine sahip katılımcılara istinaden fazla olduğu belirlenmiştir.

Turist rehberlerinin hizmet kalitesinin ve destinasyon imajının alt boyutları açısından regresyon analizine, hizmet kalitesini oluşturan her bir alt boyutun (somut ögeler, güvenilirlik, empati, isteklilik ve güvence) destinasyon imajı üzerinde anlamlı etkiye sahip olduğu görülmüştür Buna ek olarak, somut ögeler, güvenilirlik, empati ve güvence alt boyutları destinasyon imajı üzerinde pozitif etkiye sahip iken; isteklilik boyutunun destinasyon imajı üzerindeki etkisinin negatif olduğu gözlemlenmiştir. Sonuçlar 1şığında, Konya'yı ziyaret edenlerin, turist rehberlerinin somut ögeleri olarak sahip olduğu dış görünüşü, kullandığı materyaller ve bilgi donanımına yönelik olumlu düşüncelere sahip olmalarının, rehberin tur esnasında vermiş olduğu güvenilir tavırlara sahip olmalarının, tur rehberinin onlarla iyi anlaşarak empati kurduğuna inanmalarının ve verdiği teminatları yerine getirerek onlara güvence sağladığını düşünmelerinin destinasyon imajını oluşturan duygusal, bilişsel ve genel her bir alt boyutu üzerinde etkili birer faktör olduğu düşünülebilir.

Hizmet kalitesinin alt boyutlarından güvence destinasyon imajını oluşturan alt boyutlarından bilişsel imaj üzerinde daha yüksek düzeyde etkili olduğu tespit edilmiştir. Buna göre, Konya'yı ziyaret eden turistlere yönelik sunulan rehberlik hizmetinde turistlerin tur esnasında başlarına gelmesi öngörülen herhangi problemde hem maddi hem de manevi olarak rehberin yanlarında olmaları, ayrıca turu zamansal olarak iyi idare etmeleri gerektiğini düşünmektedir. Dolayısıyla, Konya'da bulunan rehberli tur düzenleyen turizm işletmeleri başta olmak üzere, bu destinasyonun pazarlanmasında büyük etkisi olan şehrin imajından yetkili ve sorumlu olan diğer tüm paydaşların söz konusu hizmet kalitesi alt boyutunun önemini anlamaları elzemdir.

Turist rehberlerinin hizmet kalitesinin, isteklilik al boyutunun destinasyon imajının tüm alt boyutlarının üzerinde anlamlı olmasına rağmen negatif etkiye sahip olması beklenmedik bir sonuç olarak karşımıza çıkmaktadır. İsteklilik alt boyutunun ifadelerinin katılımcıların zihninde anlamlaştırmasının zor olması da bu sonucu doğurmuş olabilir. Bu sonucun oluşmasındaki bir başka neden ise cevaplayıcıların diğer ölçek alt boyutlarının fazla puanlaması olabilir.

Araştırmanın bulguları, turist rehberi hizmet kalitesinin, destinasyon imajı üzerinde pozitif ve anlamlı bir etkiye sahip olduğunu göstermektedir. Böylece araştırmanın ana hipotezi desteklenmektedir. Bu araştırma, turizm literatüründe bu konuya odaklanan çok az sayıdaki çalı̧̧malardan biridir. Ayrıca çalışma, turist rehberlerinin ve tur operatörlerinin tüm turist rehberlerinin hizmet kalitesi alt boyutlarının önemli rolünü anlamalarına yardımcı olacaktır. Bu nedenle, kısa veya uzun vadeli stratejilere dayanarak, tur operatörleri/acenteler, bir tur esnasında turist rehberlerinin hizmet kalitelerini artırmak için bu alt boyutlara 
odaklanabilir. Turist rehberinin hizmet kalitesi aslında sadece bir paket turunun başarısını etkilemekle kalmamakta, aynı zamanda Konya'daki turizm endüstrisinin imajını oluşturmasında da önemli bir rol oynamaktadir. 


\section{KAYNAKÇA}

Ahipaşaoğlu, S. (2001). Seyahat İşletmelerinde Tur Planlaması ve Yönetimi, Detay Yayıncılık, Ankara.

Altunışık, R., Çoşkun R., Bayraktaroğlu, S., \& Yıldırım, E. (2012). Sosyal Bilimlerde Araştırma Yöntemleri, Sakarya Yayıncilık, Sakarya.

Ap, J. and Wong, K.K.F. (2001). Case Study on Tour Guiding: Professionalism, Issues and Problems, Tourism Management, Vol.22, pp. 551-563.

Arreola, M.R. (1998). Group Says Its Role Is to Raise Standards for S.A. Tour Guides, San Antonio Business Journal, Vol. 12, No. 27, pp. 19-20.

Baloğlu, S., and McCleary, K. W. (1999). A model of destination image formation. Annals of Tourism Research, Vol.26, No.4, pp. 868-897.

Baum, T. Hearns, N. and Devine, F. (2007). Place, People and Interpretation: Issues of Migrant Labour and Tourism Imagery in Ireland, Tourism Recreation Research, Vol. 32, No.3, pp. 39-48.

Boon-itt, S. and Rompho, N. (2012). 'Measuring Service Quality Dimensions: An empirical analysis of Thai hotel industry', International Journal of Business Administration, 3(5), pp. 52-63.

Cherem, G.J. (1977). The Professional Interpreter: Agent for an Awakening Giant, Journal of Interpretation, Vol.2, No.1, pp. 3-16.

Cohen, E. (1985). The Tourist Guide: The Origins, Structure and Dynamics of a Role, Annals of Tourism Research, Vol. 12, pp. 5-29.

Cohen, E., Ifergan, M. and Cohen, E. (2002). A New Paradigm of Guiding: The Madrich as a Role Model, Annals of Tourism Research, Vol. 29, pp. 919-932.

Crompton, J. L. (1979). Motivations of Pleasure Vacation. Annuals of Tourism Research, 6 (4), 408-424.

Çetin, G., Kızılırmak, İ. (2012) “Türk Turizminde Kokartlı Turist Rehberlerin Mevcut Durumunun Analizi”, Afyon Kocatepe Üniversitesi, İIBF Dergisi, (14) 3, ss. 307-318.

Dahles, H. (2002). The Politics of Tour Guiding: Image Management in Indonesia, Annals of Tourism Research, Vol. 26, pp. 267-293.

Değirmencioğlu, A.Ö. (2001). Fransız Turistlerin Anadolu Turlarında Rehberlik Hizmetinden Tatmin Düzeyleri Üzerine Ampirik Bir İnceleme, Sosyal Bilimler Enstitüsü, Turizm İşletmeciliği Ana Bilim Dalı, Gazi Üniversitesi, Yayınlanmamış Yüksek Lisans Tezi.

Echtner, C. M., J. R. B. Ritchie (1991), The Meaning and Measurement of Destination Image, The Journal of Tourism Studies, Vol. 2, No.2, (December), 2-12.

Echtner, C. M. and J. R. B. Ritchie (1993), The Measurement of Destination Image: An Empirical Assessment, Journal of Travel Research, (Spring), 3-13.

Fakeye, P. C., Crompton, J. L. (1991). Image Differences Between Prospective, First-Time, and Repeat Visitors to the Lower Rio Grande Valley, Journal of Travel Research, Vol.30, No.2, pp. 10-16.

Geva, A., Goldman, A. (1991). Satisfaction Measurement in Guided Tours, Annals of Tourism Research, Vol. 18, No.2, pp. 177-185.

Heung, Vincent C. S., (2008) “Effects of Tour Leader's Service Qualityon Agency's Reputation Andcustomers' WordOf-Mouth", Journal of Vacation Marketing, 14(4), pp. 305-315.

Holloway, J. (1981). The Guided Tour: A Sociological Approach, Annals of Tourism Research, Vol.8, pp.377-402.

Hunt, J. D. (1971). Tourism Marketing and Management. Prentice Hall, Cambridge.

Karasar, N. (2012). Bilimsel Araştırma Yöntemi (23. Basım), Nobel Yayıncılık, Ankara.

Keskin, M. (2013). Konaklama İşletmelerinde İşgörenlerin Hizmet Kalitesi Algılamaları: Sinop İlinde Faaliyet Gösteren Konaklama İşletmelerine Yönelik Bir Uygulama, Sosyal Bilimler Enstitüsü, Turizm İşletmeciliği Ana Bilim Dalı, Adnan Menderes Üniversitesi, Yayınlanmamış Yüksek Lisans Tezi.

Lawson, F., and Baud-Bovy, M. (1977). Tourism and Recreational Development. Architectural Press, London.

Mak, Athena H. N., Wong, K. K. F., Chang, R. C. Y., (2010) "Factors Affecting the Service Quality of the Tour Guiding Profession in Macau", International Journal of Tourism Research, 12, pp. 205-218.

Markin, J. R. (1974). Consumer behavior: A cognitive orientation. Macmillan, Hampshire, London.

Milman, A. and A. Pizam (1995), The Role of Awareness and Familiarity with a Destination: the Central Florida Case, Journal of Travel Research, 35 (Winter), 21-27.

Moscarado, G. (1998). Interpretation and Sustainable Tourism: Functions, Examples and Principles, Journal of Tourism Studies, Vol. 9, No.1, pp.2-13.

Moscardo, G. (1996). Mindful Visitors, Annals of Tourism Research, Vol. 23 No. 2, pp. 376-87.

Mossberg, Lotta L., (1995) "Tour Leaders and Their Importance in Charter Tours", Tourism Management, 16(6), pp. 437-445.

Otto, J. E., and Ritchie, J. R. B. (1996). The service experience in tourism. Tourism Management, 17(3), 165-174.

Parasuraman, A., Zeithaml, V.A. and Berry, L.L. (1988). 'SERVQUAL: a multi-item scale for measuring consumer perceptions of service quality', Journal of Retailing, 64(1), pp. 12-40.

Pearce, P.L. (1984). Tourist-Guide Interaction, Annals of Tourism Research, Vol. 11, pp. 129-146.

Pond, K. (1993). The Professional Guide: Dynamics of Tour Guiding, Van Nostrand Reinhold, New York. 
Rabotić, B., (2010). Tourist Guides in Contemporary Tourism, International Conference on Tourism and Environment Sarajevo, Bosnia and Herzegovina, pp. 1-12.

Resmi Gazete, 22.06.2012. 6326 Sayıl1 “Turist Rehberliği Meslek Kanunu”.

Reynolds, W. H. (1985). The role of the consumer in image building. California Management Review, 7(3), 69-76.

Schmidt, C. J. (1979). The Guided Tour: Insulated Adventure. Journal of Contemporary Ethnography, Vol.7, No.4, pp. 441-467.

Timur, B. (2015). Termal Turizmde Hizmet Kalitesi Algılanan Destinasyon imajı ve Tekrar Ziyaret Niyeti Arasındaki İlişkilerin İncelenmesi, Sosyal Bilimler Enstitüsü, Turizm İşletmeciliği Ana Bilim Dalı, Eskişehir Osmangazi Üniversitesi, Yayınlanmamış Yüksek Lisans Tezi.

Ural, A., Kılıç, G. (2006). Bilimsel Araştırma Süreci ve SPSS ile Veri Analizi. Ankara: Detay Yayıncılık.

Wang, K. C., Hsieh, A.T., Huan, T.C., (2000). Critical Service Features in Group Package Tour: An Exploratory Research. Tourism Management, 21, pp. 177-189

Whipple, T. W. and Sharon, V. (1988). Group Tour Management: Does Good Service Produce Satisfied Customers?, Journal of Travel Research, Vol.27, No.2, pp. 16-21.

Wong, A., (2001). Satisfaction with local tour guides in Hong Kong. Pacific Tourism Review, 5(1), pp. 59-67.

Yaraşlı, G. Y. (2007). Destinasyon İmajı ve Trabzon Yöresine Dönük Bir Çalışma, Sosyal Bilimler Enstitüsü, İşletme Ana Bilim Dalı, Başkent Üniversitesi, Yayınlanmamış Yüksek Lisans Tezi.

Zhang, H.Q. and Chow, I. (2004). Application of Importance-Performance Model in Tourguides' Performance: Evidence from Mainland Chinese Outbound Visitors in Hong Kong, Tourism Management, Vol. 25, pp. 81-91. 